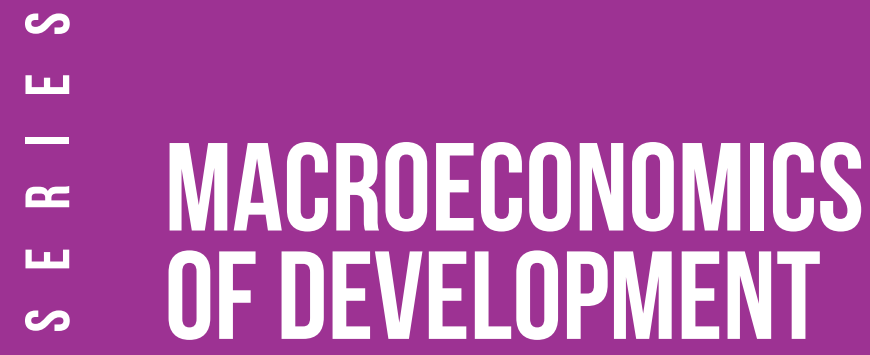

\title{
Income inequality in Latin America
}

Recent decline and prospects for its further reduction

Giovanni Andrea Cornia
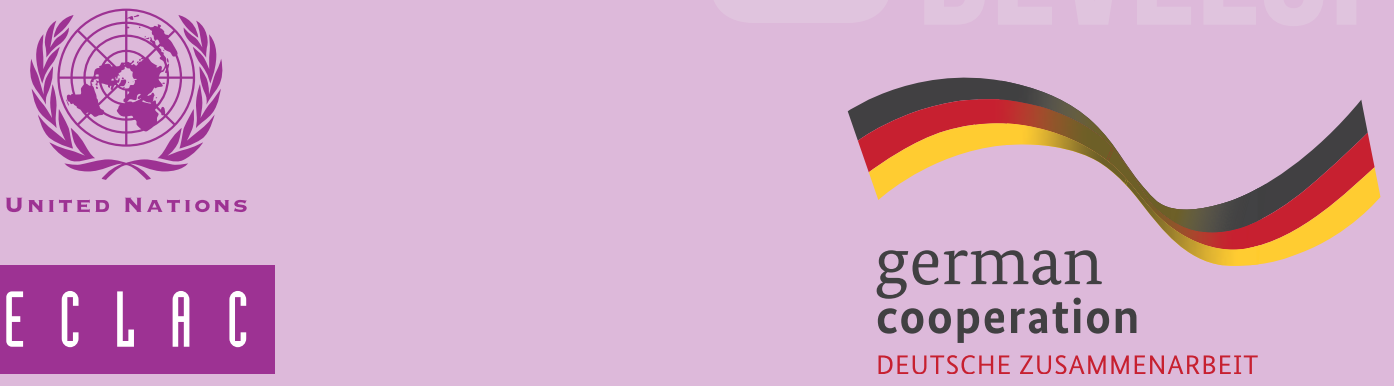


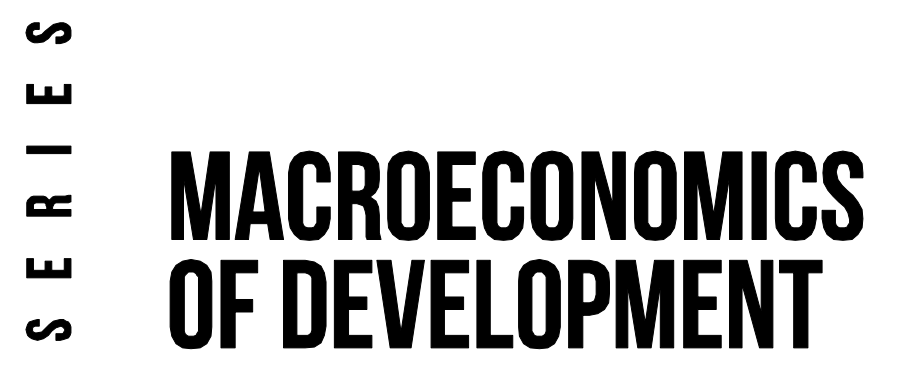

\section{Income inequality in Latin America}

Recent decline and prospects

for its further reduction

Giovanni Andrea Cornia 
This document has been prepared by Giovanni Andrea Cornia, Department of Economics, University of Florence, and consultant of the Economic Development Division of the Economic Commission for Latin America and the Caribbean (ECLAC), within the activities of the project ECLAC/GIZ: Pacto fiscal para el crecimiento con igualdad (GER/12/005).

The views expressed in this document, which has been reproduced without formal editing, are those of the author and do not necessarily reflect the views of the Organization.

United Nations publication

ISSN 1680-8843

LC/L.3847

Copyright @ United Nations, July 2014. All rights reserved

Printed at United Nations, Santiago, Chile

Member States and their governmental institutions may reproduce this work without prior authorization, but are requested to mention the source and inform the United Nations of such reproduction. 


\section{Contents}

Abstract 5

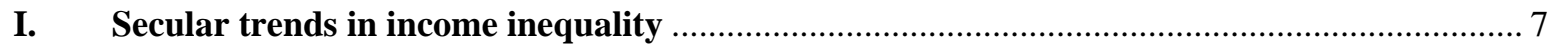

A. Evolution of income inequality during the 1980s and 1990s ................................................... 8

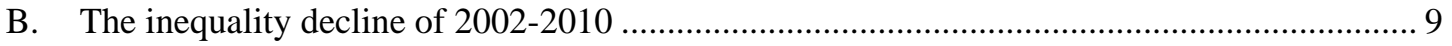

1. Extent and speed of the decline................................................................................. 9

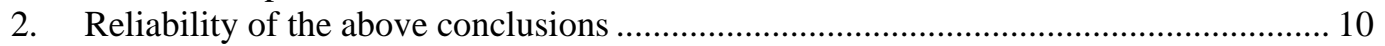

3. Beneficiaries of the decline in inequality ...................................................................... 12

4. Income decline by political orientation of governments ............................................... 13

5. Comparing the 2000s Latin America's inequality trend with that of other regions ........ 13

II. Underlying causes of the decline of income inequality over 2002-2010 .............................. 17

A. An improvement in external conditions ................................................................................. 17

B. Impact of the rapid growth of 2002-2008 and 2010 on income inequality ........................... 18

C. An improvement in the distribution of educational achievements ............................................ 18

D. The spread of progressive regimes and new policy approaches.......................................... 19

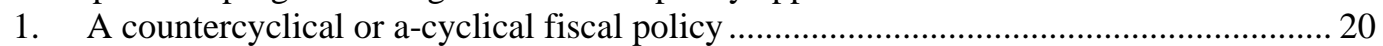

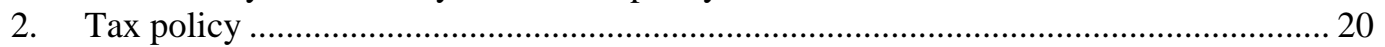

3. A countercyclical monetary policy ……………........................................................... 21

4. Exchange rate regime.................................................................................................. 21

5. Trade and external indebtedness .................................................................................. 22

6. Labour market policies............................................................................................ 22

7. Rising social expenditure, social assistance and redistribution....................................... 23

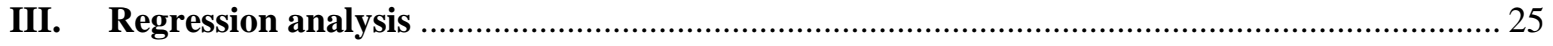

A. Dataset and bilateral correlation coefficients among explanatory variables .......................... 25

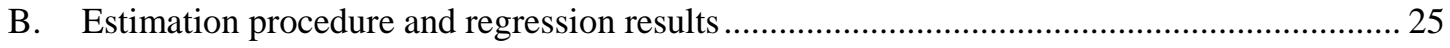

IV. Inequality during the crisis of 2008-2012 and prospects for its further reduction............... 29

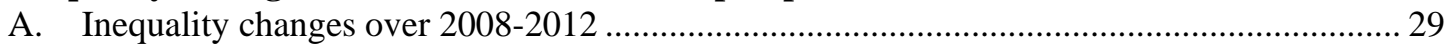

B. Further reducing inequality through a deepening of the recent reforms .................................. 30

1. Improve further the equality of opportunities among social classes ............................... 31 
2. Raising revenue/GDP ratios - and improve the targeting of social expenditure............. 32

C. Embed the decline of income inequality in a sustainable pattern of growth........................... 33

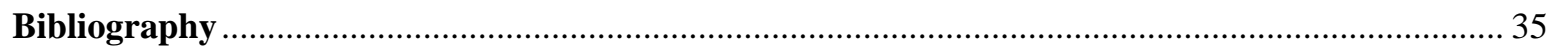

Annex 39

Macroeconomics of Development Series: Issues published 41

Tables

TABLE 1

RATIO OF HOURLY WAGES OF WORKERS WITH HIGH AND LOW EDUCATION

TABLE 2 CHANGES IN THE INCOME SHARES OF THE POOR (QUINTILES 1-5), 'MIDDLE CLASS' (QUINTILES 6-9) AND RICH (QUINTILE 10) DURING 1990-2002 (RISING INEQUALITY) AND 2002-2009 (FALLING INEQUALITY)

TABLE 3 INEQUALITY TRENDS FROM THE EARLY UNTIL THE LATE 2000s (DEPENDING ON THE LATEST AVAILABLE DATA) BY THE IDEOLOGICAL PROFILE OF GOVERNING PARTIES

TABLE 4 TREND IN THE GINI COEFFICIENT OF THE DISTRIBUTION OF HOUSEHOLD DISPOSABLE INCOME PER CAPITA, 1980-2000 AND 2000-2010 .15

TABLE 5 LABOUR MARKET TRENDS FOR LATIN AMERICA AS A WHOLE, 1990-2009

TABLE 6 DECOMPOSITION OF THE INCREASE IN PUBLIC SPENDING IN EDUCATION PER CHILD AGED 0-14 BY ITS MAIN DRIVERS, SELECTED COUNTRIES ...............19

TABLE 7 REYNOLDS-SMOLENSKY INDEX (GINI POINTS) FOR THE 1990s AND 2000s ........21

TABLE 8 TREND IN THE INDEX OF REAL MINIMUM WAGES IN SELECTED COUNTRIES .22

TABLE 9

TABLE 10 REGRESSION RESULTS OVER THE PERIOD 1990-2009: AVERAGE REGIONAL EFFECTS AND RESULTS FOR HETEROGENEOUS SUB-GROUPS ...........................27 NET TERTIARY ENROLMENT RATES, TOTAL AND BY INCOME QUINTILES, $1990-2010$ 31

TABLE A.1 DEFINITION OF VARIABLES USED IN REGRESSION ANALYSIS

40

Figures

FIGURE 1 POPULATION WEIGHTED GINI ESTIMATES AND CONJECTURES FOR LATIN AMERICA 7

FIGURE 2 TREND IN THE AVERAGE REGIONAL GINI INDEX OF THE DISTRIBUTION OF HOUSEHOLD INCOME PER CAPITA, EARLY 1980-2010 .10

FIGURE 3 TREND IN THE GINI COEFFICIENT BASED ON HOUSEHOLD BUDGET SURVEYS (SOLID LINE) AND IN THE GINI REVISED ON THE BASIS OF THE INCOME SHARE OF THE TOP 1\% DERIVED FROM TAX RETURNS (SEGMENTED LINE)

FIGURE 4 TAX REVENUE, PUBLIC EXPENDITURE AND PRIMARY BALANCE, $1995-2010$

FIGURE 5 TREND IN 30

FIGURE 6 2008-2012 32 


\section{Abstract}

The paper reviews the extent of the income inequality decline which has taken place in Latin America over 2002-2010 which reduced the regional Gini index to the level of the early 1980s. The paper then focuses on the factors which may explain such decline. These include a drop in the skill premium following an expansion of secondary education, the adoption of a new development model by a growing number of progressive governments which adopted prudent but more equitable macroeconomic, tax, social assistance and labor policies. For the region as a whole, gains in terms of trade, remittances, FDI and world growth played an important but not determinant role though their impact was perceptible in countries where such shocks were sizeable. Finally, the paper reviews the changes in inequality during the difficult years 2009-2012 and discusses whether and how the recent decline can be sustained over the next decade in the context of sluggish world growth. 



\section{Secular trends in income inequality}

The colonial origins of the high income inequality that has afflicted the region for almost five centuries have been well analysed by Engerman and Sokoloff (2005) who underscore that the high inequality in the distribution of land and political power inherited from the colonial regimes led to the development of institutions which perpetuated well into the post — Second World War- period the privileges of a small agrarian and commercial oligarchy by facilitating the diversification of their assets from agriculture, mining and commerce into industry and finance. Prado de la Escosura (2005) adds to this view that the improvement in international terms of trade experienced by Latin America during the globalization of 1870-1914 raised land yields and land rental/wage ratios benefitting a tiny class of large landowners. The trend towards rising inequality was interrupted during the inter-war years, which witnessed a decline in world trade (Figure 1), but recovered in the post World War II period (ibid).

FIGURE 1

POPULATION WEIGHTED GINI ESTIMATES AND CONJECTURES FOR LATIN AMERICA

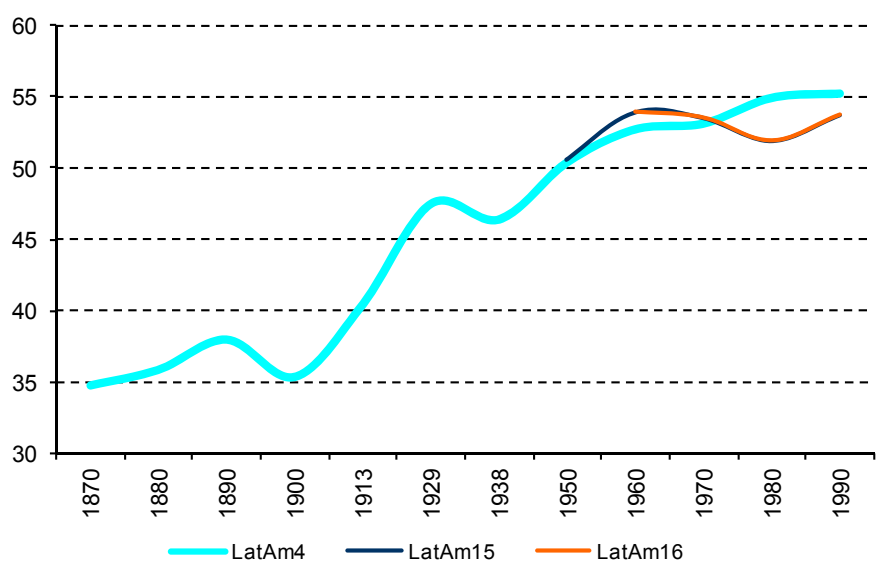

Source: Author's elaboration on data reported in Prados de la Escosura (2005: 39). 
As a result, in the early 1950s the region was characterized by high structural inequality, which depended on: (i) a high land concentration, with Gini coefficients of land distribution ranging between 0.61 (Mexico) and 0.93 (Paraguay) as opposed to between 0.29 and 0.56 in Asia and Africa (Frankema 2009); (ii) an unequal distribution of human capital; (iii) the 'curse of natural resources' by which the countries endowed with natural resources exhibited high levels of concentration of assets and personal income; (iv) an urban bias resulting from overvalued exchange rates, pricing policies that penalized agriculture, a biased spatial allocation of public expenditure, and the drainage of rural savings, with the result that around 1950 rural incomes per head ranged between one-quarter and one-half of urban incomes (ibid. Table 12.6). In view of all of this, with the exception of Uruguay and Argentina, the Gini coefficient of the distribution of income in the early-mid 1950s ranged between 0.47 and 0.65, i.e., among the highest in the world.

Between the 1950s and 1982, the years of import substituting industrialization (ISI), income inequality declined only moderately in much of the region due to the urban bias of the ISI policies. However, inequality fell markedly until the mid-1970s in Argentina, Costa Rica, Uruguay and Venezuela due to urbanization, the introduction of an income tax, and the creation of an embryo of redistributive policies. The 1970s witnessed a bifurcation of inequality trends. While, as noted, inequality fell moderately in most of the region, it rose in the Southern Cone (Gasparini et al. 2009) where an extreme version of the neoliberal reforms had been implemented by military juntas.

\section{A. Evolution of income inequality during the 1980 s and 1990 s}

From the mid-late 1970s, and increasingly so from the beginning of the 1980s, most Latin American countries abandoned the ISI paradigm and introduced neoliberal policies in the fields of stabilization, liberalization, and privatization. These measures paved the way to the liberalization of international trade, FDI and portfolio flows. Their supporters claimed that these policies would have restored the conditions for growth and that, in line with the predictions of the Stolper-Samuelson corollary of the Hercksher-Ohlin theorem, trade and capital account liberalization would have improved domestic inequality in nations with an abundant supply of unskilled labour.

The distributive impact of both orthodox (and heterodox) approaches of the 1980s was regressive. During the 1980s inequality fell only in Colombia, Costa Rica, Honduras and Peru (Altimir 1996; Londoño and Székely 2000). Despite the return to a moderate growth and extensive internal and external liberalization, income concentration during the 1990s worsened further in almost two-thirds of the cases, albeit at a slower pace than in the 1980s (Gasparini et al. 2009; Figure 2). As a result, the average regional Gini index rose by 2.2 points from the early 1980s to 1990, by another 1.7 points between 1990 and 2000, and by 1.2 points during the recession of 2001-2002, that is by 5.1 points for the two neoliberal decades. A key feature of this trend was the decline of the labour share in total income and the parallel rise in the capital share (Sainz and Calcagno 1992). Five structural changes explain this remarkable shift. First, with the economic stagnation of the 1980s, the regional unemployment rate rose sharply between 1990 and 2002. Second, there was a substantial shift of labour to the informal sector. Third, formal sector wages rose more slowly than GDP per capita while the minimum/average wage ratio fell and wage differentials by skill widened (ibid).

What factors explain the trends of the 1980s and 1990s? Barring an aggravation of the structural causes of inequality mentioned above, the literature focuses on two complementary explanations: the skill-biased technical change (SBTC) and the impact of liberal policies. The main effect of the SBTC induced by trade liberalization was to raise the demand for skilled workers to operate the newly imported machines while its supply remained rigid because of low past public expenditure on education and the inability of the poor to borrow. While there is evidence that the relative wage of skilled workers rose in the 1990s (Table 1), it is not obvious that this was solely due to the SBTC induced by trade liberalization rather than institutional and demographic factors. Indeed, while trade liberalization eased the import of labour-saving skill-biased capital goods, the depressed climate prevailing in the region offered few incentives to invest in new equipment. Indeed, the regional investment/GDP ratio fell from 22 per cent in 1980 to 16 per cent for the rest of the decade and 18 per cent in the 1990s, while it rose to 
24 per cent in 2008 in parallel with a drop in the skill premium. In contrast, there is consistent evidence of the impact of liberalization on income inequality. Behrman, Birdsall and Székely (2000) found in a study on 18 Latin American countries for 1980-1998 that liberalization caused an overshooting of inequality which was particularly intense on occasion of domestic financial reforms, capital account liberalization and regressive tax reforms. Similar results were obtained by Taylor (2005), Koujianou Goldberg and Pavcnik (2007) and Gasparini and Cruces (2010) for Argentina. Though with different emphasis, these studies conclude that domestic, trade and financial liberalization generated adverse distributive effects due to competition by low-cost imports and the ensuing job losses, the immobility of production factors in the declining sector, skill-biased technical change, informalization of employment following a rise of the real exchange rate, and devastating macro and financial crises.

TABLE 1

RATIO OF HOURLY WAGES OF WORKERS WITH HIGH AND LOW EDUCATION

\begin{tabular}{|c|c|c|c|c|c|c|c|c|c|c|c|c|c|}
\hline \multirow{2}{*}{$\begin{array}{l}\text { Country } \\
\text { Argentina }\end{array}$} & \multicolumn{2}{|c|}{ 1989/1991 } & \multicolumn{2}{|c|}{$2000 / 2001$} & \multicolumn{2}{|c|}{2009} & \multirow{2}{*}{$\begin{array}{l}\text { Country } \\
\text { Guatemala }\end{array}$} & \multicolumn{2}{|c|}{ 1989/1991 } & \multicolumn{2}{|c|}{$2000 / 2001$} & \multicolumn{2}{|c|}{2009} \\
\hline & 2.26 & & 2.65 & $\uparrow$ & 2.21 & $\downarrow$ & & - & & 5.64 & & 4.09 & $(' 04) \downarrow$ \\
\hline Bolivia & 3.75 & ('93) & 4.75 & $\uparrow$ & 2.84 & $\downarrow$ & Honduras & 5.09 & & 4.29 & & 4.10 & $\downarrow$ \\
\hline Brazil & 6.11 & & 5.90 & & 4.27 & $\downarrow$ & Mexico & 3.19 & & 4.50 & $\uparrow$ & 3.91 & $\downarrow$ \\
\hline Chile & 3.37 & & 4.18 & $\uparrow$ & 3.20 & $\downarrow$ & Nicaragua & 3.08 & ('93) & 3.62 & $\uparrow$ & 3.73 & \\
\hline Colombia & 3.39 & & 4.82 & $\uparrow$ & 4.08 & $\downarrow$ & Panama & 3.33 & & 3.91 & $\uparrow$ & 3.29 & $\downarrow$ \\
\hline Costa Rica & 3.01 & & 2.68 & & 3.06 & & Paraguay & 3.44 & & 3.78 & $\uparrow$ & 2.36 & $\downarrow$ \\
\hline $\begin{array}{l}\text { Dominican } \\
\text { Republic }\end{array}$ & 2.30 & ('97) & 2.64 & $\uparrow$ & 2.50 & $\downarrow$ & Peru & 2.77 & ('97) & 2.04 & & 2.73 & \\
\hline Ecuador & 2.93 & ('94) & 3.00 & $\uparrow$ & 2.50 & $\downarrow$ & Uruguay & 2.50 & & 2.75 & $\uparrow$ & 2.72 & $=$ \\
\hline El Salvador & 3.18 & & 3.64 & & 3.83 & ('08) & Venezuela & 2.59 & & 2.08 & & 2.05 & ('06) \\
\hline
\end{tabular}

Source: Author's elaboration on SEDLAC database (July 2011). Note: similar trends are evident when comparing the ratio of hourly wages of workers with high and medium education.

\section{B. The inequality decline of $\mathbf{2 0 0 2 - 2 0 1 0}$}

\section{Extent and speed of the decline}

Between 2002 and 2010 inequality fell —albeit to a different extent and with different timing — in all 18 countries analysed with the exception of Nicaragua and Costa Rica. As a result, the unweighted regional Gini — which had risen by 0.32 Gini points a year during the 1980s and 0.16 during the $1990 \mathrm{~s}$ - fell by 0.50 points over 2002-08, 0.47 in the crisis year of 2009 and a staggering 1.93 in 2010 (Figure 2, for country details see Cornia 2014, Table 2.1). ${ }^{1}$ All this seems to point to a non-cyclical behaviour of the Gini coefficient and to a ceratin stability of distributive policies in the region (see Part 5). Finally, it is worth-noting that the recent average Gini decline per year was much more sizeable than the earlier rises, so that by 2010 the average regional Gini had returned to the pre-Washington consensus level of inequality of the early 1980s (Figure 2).

Thanks to the large inequality drop recorded in Argentina, Brazil, Peru and Venezuela (Bolivarian Republic of) and, of late Mexico, the extent of the GDP or population weighed Gini decline would be greater. 
TREND IN THE AVERAGE REGIONAL GINI INDEX OF THE DISTRIBUTION OF HOUSEHOLD INCOME PER CAPITA, EARLY 1980-2010

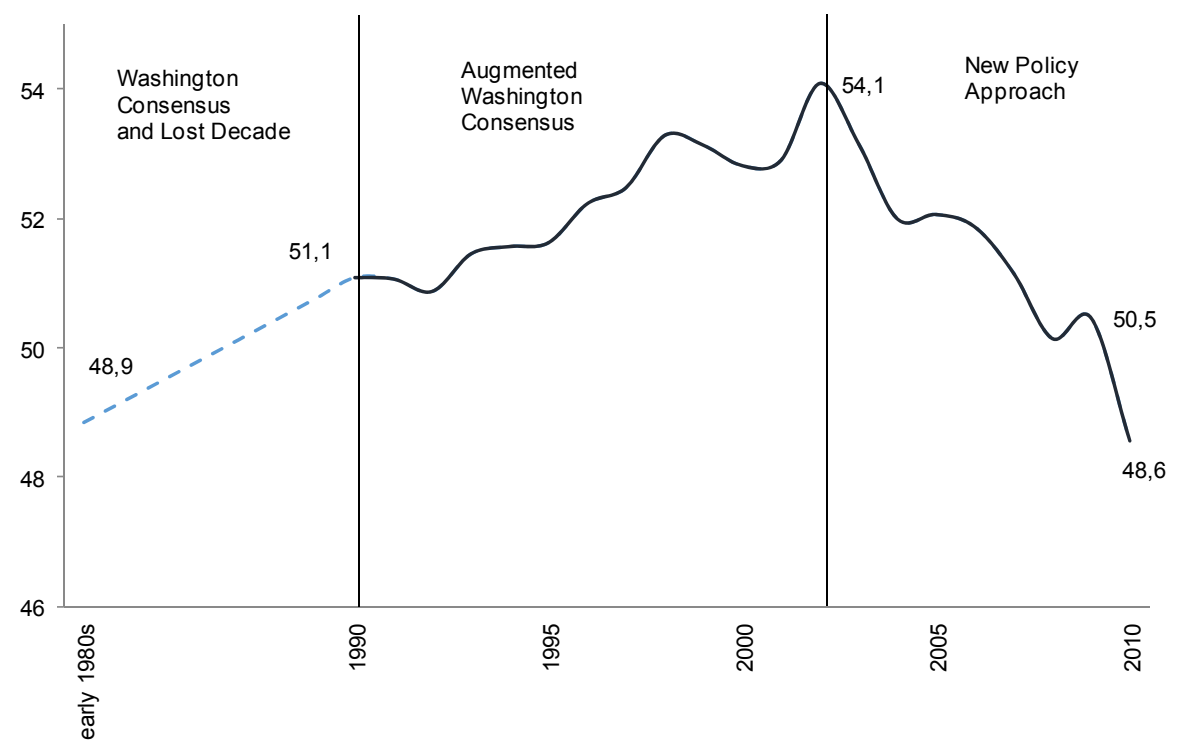

Source: Cornia (2014).

There is evidence that part of the inequality gains of the last decade can be attributed to a rebound from the 2001-2002 crisis, and that the rate of decline of the regional Gini coefficient slowed down over 2004-2006 (Figure 2). However, the average drop in inequality recorded in the region during 2002-2004 (2.55 Gini points) was considerably greater than its 2000-2002 rise (1.55 points), while during the biennium 2006-2008 there was a further decline which, as noted, continued or even accelerated during the crisis of 2009 (as in Honduras and Panama) and during the recovery of 2010 (as in Mexico and Uruguay). Overall, the 'rebound effect' seems to explain about a third of the overall regional decline recorded between 2002 and 2010. This suggests that two-thirds of the inequality drop constitutes a reversal of the 'liberalization-globalization inequality' of the 1980s and 1990s (Figure 2).

\section{Reliability of the above conclusions}

It could be argued that these conclusionsmight be biased by the grossly incomplete accounting of top incomes in household budget surveys due to a sistematic under-sampling, under-reporting and truncation of the incomes of the top 1\%, or to the fact that the elites receive considerable incomes on the substantial part of their assets which they held abroad. In this regard, the analyses of income distribution changes based on tax returns data by Alvaredo (2010) show that G (the Gini coefficicnt corrected on the basis of the formula $G=G^{*}(1-S)+S$, where $G^{*}$ is the Gini coefficient computed on household surveys and $S$ is the income share of the top 1\% computed on tax returns) is always higher than the the HBS Gini by 3-8 points. In addition, Alvaredo (2010: 7) notes on Argentinean data that:

'...not only can [Gini] levels be different, but also the trends of $G$ and $G^{*}$ can diverge. According to the survey's results, G* displays virtually no change when 2001 and 2003 are compared, going from 51.1 to 50.9. However, G “corrected” with the top 1 per cent income share ....was 57.4 in 2001 and 59.2 in 2003 (almost a two percentage points increase).’.

Which means that the inequality trends corrected by the income share of the top $1 \%$ may not have followed th trend depicted in Figure 2. To verify this hypothesis we use the only data computed by Latin American researchers which compare the trends in $G^{*}$ and $G$. This type of analysis for the last decade exists only for Argentina 2001-2004 (Alvaredo 2010), Colombia 2007-2010 (Alvaredo and Londono 2013), and Uruguay 2009-2011 (Burdin et al. 2013). Such assement however shows that while the 
corrected G is always higher than the uncorrected one, the trends are basically the same (Figure 3). We have therefore a 'level effect' but not a 'trend effect' — which means that the conclusions reached on the uncorrected datasets hold.

FIGURE 3

TREND IN THE GINI COEFFICIENT BASED ON HOUSEHOLD BUDGET SURVEYS (SOLID LINE) AND IN THE GINI REVISED ON THE BASIS OF THE INCOME SHARE OF THE TOP 1\% DERIVED FROM TAX RETURNS (SEGMENTED LINE).
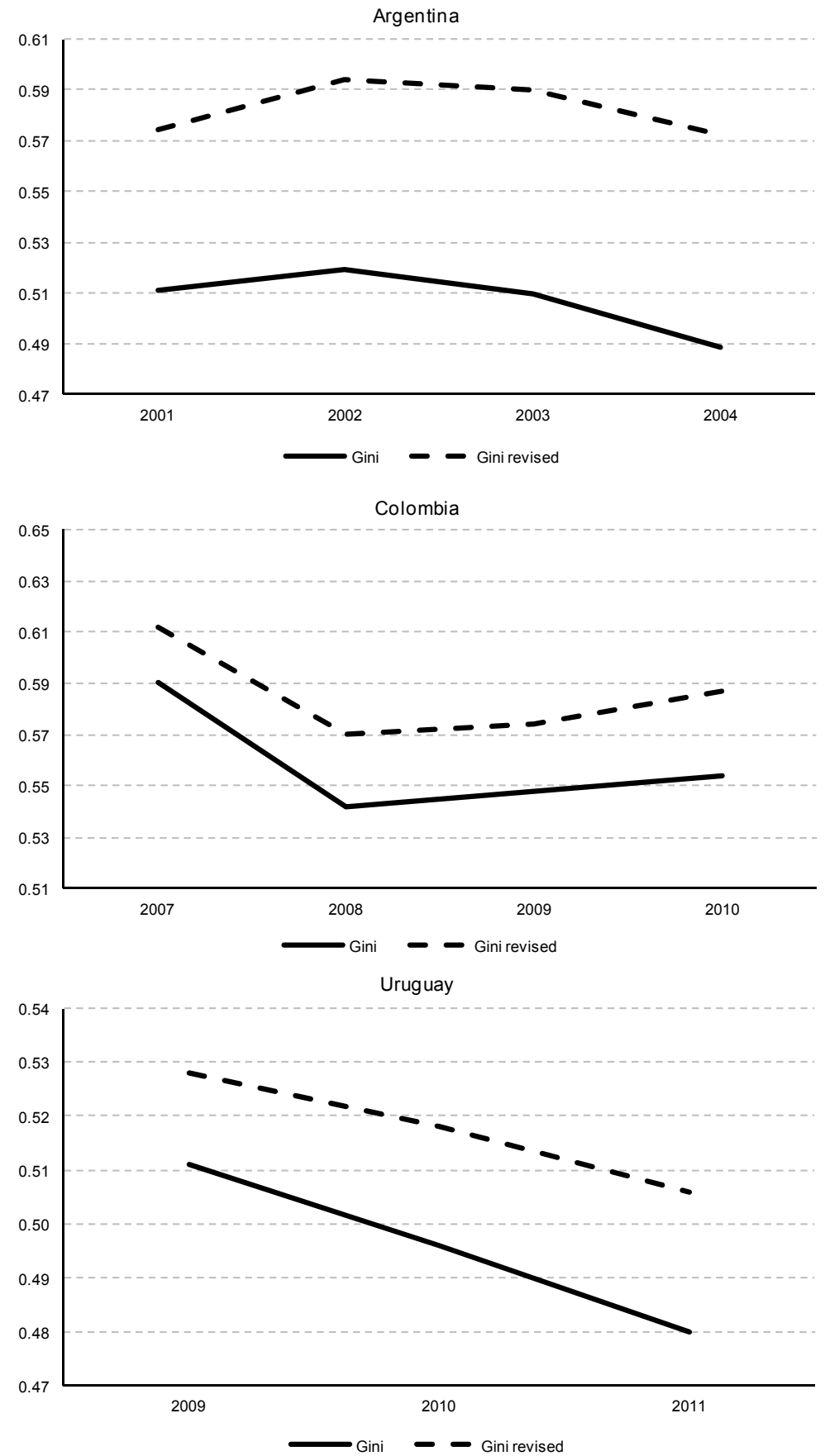

Source: Jimenez (2014). 


\section{Beneficiaries of the decline in inequality}

A key issue -including in political terms (see below) - concerns the identification of the social classes which benefitted from the recent inequality decline. In this regard, an interesting paper by Palma (2011) covering the developing and transitional economies claims that the income share of the middle class (which he defines as deciles 5-9) has remained constant over time at around 45-55 percent of national income. In his views, any inequality change is due to changes in the income shares of the top $10 \%$ and bottom $40 \%$ which vary substantially across countries and over time. The reason for the supposed stability of its income share is that the middle class has acquired (for mysterious reasons) strong 'property rights' over about half of the national income. Thus, the overall changes in income distribution basically depend on the distributive fight between the rich and the poor.

While the emphasis on the role of the middle class as a driver of efficient and equitable reforms is warranted, ${ }^{2}$ an examination of the changes in income share of the poor, middle class and rich for the Latin American countries over 1990-2010, does not support Palma's conclusions. Indeed, in most countries, both the poor and the middle class suffered a loss of income share between 1990 and 2002 and both benefitted from the inequality decline of 2002-2009. In this regard, Table 2 shows that in 6 of the 9 cases in which the Gini coefficient rose over 1990-2002 the middle class (deciles 6-9) experienced an often sizeable decline of its income share. Indeed, in some cases, the middle class lost a share of national income bigger than that of the poor (deciles 1-5) (Table 2). Furthermore, during the years of falling inequality of 2002-2009 the income share of the middle class improved significantly in 11 of the 15 countries which experienced distributive gains, although, on average, such gains were less marked than those of the poor. It thus appear that, though with differences from country to country, the recent exogenous shocks and policy reforms benefited a fairly broad section of the population, a fact that may explain (or result from) the shift in political regimes in the region during that period (see next section).

TABLE 2

CHANGES IN THE INCOME SHARES OF THE POOR (QUINTILES 1-5), 'MIDDLE CLASS' (QUINTILES 6-9) AND RICH (QUINTILE 10) DURING 1990-2002 (RISING INEQUALITY) AND 2002-2009 (FALLING INEQUALITY)

\begin{tabular}{|c|c|c|c|c|c|c|c|c|c|c|}
\hline \multirow[b]{2}{*}{ Country } & \multirow[b]{2}{*}{ 1990-2002 } & \multicolumn{3}{|c|}{ Income deciles } & \multirow{2}{*}{$\Delta$ Gini } & \multicolumn{4}{|c|}{ Income deciles } & \multirow{2}{*}{$\Delta \mathrm{Gin}$} \\
\hline & & $1-5$ & $6-9$ & 10 & & 2002-09 & $1-5$ & $6-9$ & 10 & \\
\hline Argentina & $1990-2002$ & -4.68 & +0.94 & +3.74 & +7.7 & $2002-10$ & +5.01 & +2.81 & -7.82 & -9.0 \\
\hline Peru & $1997-2002$ & -0.67 & -2.12 & +2.79 & +2.9 & $2002-09$ & +2.99 & +4.17 & -7.18 & -6.5 \\
\hline Ecuador & $1995-2003$ & +1.82 & -1.49 & -0.33 & -2.3 & 2003-09 & +2.87 & +2.65 & -5.51 & -5.6 \\
\hline Paraguay & $1995-2002$ & +0.86 & +1.54 & -2.40 & -1.8 & $2002-09$ & +3.20 & +2.11 & -5.41 & -5.9 \\
\hline Brazil & $1990-2002$ & +1.32 & +0.07 & -1.39 & -2.1 & 2002-09 & +2.49 & +1.63 & -4.12 & -4.6 \\
\hline Panama & 1989-2002 & -0.33 & -2.46 & +2.79 & +1.4 & 2002-09 & +2.52 & +0.88 & -3.40 & -4.3 \\
\hline Venezuela & 1989-2002 & -2.97 & -0.62 & +3.68 & +5.0 & $2002-06$ & +2.45 & +0.45 & -2.90 & -4.0 \\
\hline El Salvador & $1991-2002$ & -0.45 & +2.78 & -2.33 & -0.5 & $2002-08$ & +3.76 & -0.98 & -2.78 & -5.6 \\
\hline Chile & $1990-2003$ & +0.51 & -0.28 & +0.23 & -0.5 & 2003-09 & +1.44 & +0.79 & -2.23 & -2.7 \\
\hline Bolivia & $1997-2002$ & -1.24 & -0.66 & +1.90 & +2.1 & $2002-07$ & +1.87 & +0.04 & -1.91 & -2.9 \\
\hline Honduras & 1991-2002 & -2.66 & +0.89 & +1.78 & +5.3 & 2002-09 & -0.82 & +2.46 & -1.78 & -1.4 \\
\hline Mexico & $1989-2002$ & +0.42 & +0.85 & -1.27 & -1.1 & $2002-08$ & +0.25 & +0.44 & -0.68 & -0.5 \\
\hline Guatemala & $1990-2000$ & +1.53 & -2.92 & +1.40 & -4.0 & $2000-06$ & -0.47 & +1.16 & -0.70 & -3.6 \\
\hline Dom. Rep. & $1996-2002$ & -1.61 & -0.74 & +2.35 & +2.8 & 2002-09 & +0.97 & -0.86 & -0.05 & -1.1 \\
\hline
\end{tabular}

A sizeable and relatively prosperous middle class generally plays a key role in promoting long-term growth (through capital accumulation, entrepreneurship and human capital formation), political stability, and the pursuit of lower inequality via progressive taxation, social expenditure and labor policies. 
Table 2 (conclusion)

\begin{tabular}{|c|c|c|c|c|c|c|c|c|c|c|}
\hline \multirow[b]{2}{*}{ Country } & \multirow[b]{2}{*}{ 1990-2002 } & \multicolumn{3}{|c|}{ Income deciles } & \multirow{2}{*}{$\Delta$ Gini } & \multicolumn{4}{|c|}{ Income deciles } & \multirow{2}{*}{$\Delta \mathrm{Gini}$} \\
\hline & & $1-5$ & $6-9$ & 10 & & 2002-09 & $1-5$ & $6-9$ & 10 & \\
\hline Uruguay & $1989-2002$ & -2.15 & +0.16 & +1.99 & +3.0 & $2002-09$ & +0.87 & -0.85 & -0.01 & -1.0 \\
\hline Costa Rica & 1990-2002 & -2.82 & -3.23 & +6.05 & +5.8 & $2002-09$ & -0.18 & -0.53 & +0.71 & +0.4 \\
\hline Nicaragua & $1993-2001$ & +3.63 & +1.00 & -4.63 & -4.1 & 2001-05 & -0.78 & -2.05 & +2.82 & +2.1 \\
\hline Colombia & $1996-2003$ & +0.36 & +0.84 & -1.24 & -0.9 & 2003-07 & -1.89 & -1.21 & +3.11 & +3.4 \\
\hline Average & & -0.63 & -0.30 & +0.93 & & & +1.40 & +0.73 & -2.13 & \\
\hline
\end{tabular}

Source: Cornia (2012).

\section{Income decline by political orientation of governments}

Inequality fell on average under regimes reflecting all types of political orientations, though there is a clear hierarchy of inequality falls by type of political regimes. Indeed, Table 3 suggests that the Gini coefficient was reduced by 0.54 points per year under the social-democratic left regimes, 0.42 under the radical left regimes (among which commodity exporters dominate), 0.20 under the centrist regimes, and only 0.08 under centre-right regimes. These results confirm those of Birdsall, Lustig and McLeod (2011) according to which the social-democratic left regimes improved their distribution more rapidly than the redical-left, and that both did better than the centrist and centre-right regimes.

The key question is then how to explain the political shift towards the left and the choice by the left parties of distribution-sensitive policies. As documented by the results of different waves of the Latinobarometro, such shift was to a large extent explained by growing frustration with the disappointing results of the Washington Consensus policies implemented in the 1980s and 1990s which were seen as having benefitted only a tiny elite. Among other things, the Washington Consensus policies led to a shrinkage of the industrial working class, a weakening of the unions, rising unemployment, and a substantial job informalization and self-employment. As noted by Panizza (2005), the new left parties have their roots in organizations of the working class, but have evolved into broad coalitions comprising the urban and rural poor, the unemployed and informal sector workers. They also comprise sizeale sectors of the business and of the middle classes negatively affected by the Washington Consensus measures, as shown above in Table 2. As noted by Roberts (2012) the change in political orientation of parts of the middle class was not due to an ideological realignement but to retrospsective voting, i.e. the assessment of their gains/losses during the conservative regimes. At the same time, also sections of the middle class supported the new regimes' concerns for poverty and inequality, recognition of market failures and increasing importance assigned to strengthening state institutions, i.e. a focus which is in sharp contrast with the neo-liberal emphasis on shrinking the state and the self-sustained role of markets.

\section{Comparing the 2000s Latin America's inequality trend with that of other regions}

An appreciation of the singularity of the recent distributive gains of Latin America is offered by a comparison of the inequality changes observed in other regions. In this regard, Table 4 confirms that during the broad period of 1980-2000, the majority of Latin American countries experienced an increase in inequality, a trend observed also in most other regions. In contrast, during the years 2000-10 inequality rose less frequently and less sizeably than during the previous two decades. However, only in Latin America there was a clear and generalized improvement. This bifurcation of trends is difficult to explain on the basis of the supposed advantages of the Latin American region. Most developing regions are, in fact, similarly heterogeneous. All comprise countries that depend on commodity exports, foreign capitals and remittances, as well as some semi-industrialized nations. All of them benefitted from the high commodity prices, rising remittances, financial exuberance, and rapid world growth of the last decade. Nor does the drop in inequality appear to have been driven by growth. Indeed, the fast growing 
Asian countries experienced steep rises in inequality, and China in 2010 had a higher Gini coefficient (0.47) than those of Argentina, Uruguay and Venezuela (Bolivarian Republic of).

TABLE 3

INEQUALITY TRENDS FROM THE EARLY UNTIL THE LATE 2000S (DEPENDING ON THE LATEST AVAILABLE DATA) BY THE IDEOLOGICAL PROFILE OF GOVERNING PARTIES

\begin{tabular}{|c|c|c|c|c|}
\hline & Country & Period & $\begin{array}{l}\text { Total change in Gini index } \\
\text { during each regime }\end{array}$ & $\begin{array}{l}\text { Average yearly } \\
\text { change }\end{array}$ \\
\hline \multirow{4}{*}{ Radical left } & $\begin{array}{l}\text { Bolivia (Plurinational } \\
\text { State of) }\end{array}$ & $2006-2008$ & -0.51 & -0.17 \\
\hline & Nicaragua & $2007-2008$ & no data & no data \\
\hline & Venezuela & $1999-2008$ & -6.67 & -0.67 \\
\hline & Average & & -3.59 & -0.42 \\
\hline \multirow{10}{*}{$\begin{array}{l}\text { Social democratic } \\
\text { left }\end{array}$} & Argentina & $2003-2010$ & -9.05 & -1.13 \\
\hline & Brazil & 2003-2009 & -4.56 & -0.65 \\
\hline & Chile & 2000-2009 & -3.30 & -0.33 \\
\hline & Dominican Rep. & $2000-2004$ & 0.00 & 0.00 \\
\hline & Ecuador & $2007-2010$ & -4.01 & -1.00 \\
\hline & El Salvador & $2009-2010$ & no data & no data \\
\hline & Panama & $2005-2008$ & -4.55 & -1.14 \\
\hline & Paraguay & $2008-2010$ & 0.00 & 0.00 \\
\hline & Uruguay & $2005-2010$ & -0.20 & -0.03 \\
\hline & Average & & -3.21 & -0.54 \\
\hline \multirow{7}{*}{ Centrist } & Costa Rica & 2006-2009 & +1.51 & +0.38 \\
\hline & Dominican Rep. & $2004-2010$ & -4.19 & -0.60 \\
\hline & Ecuador & $2000-2006$ & -3.01 & -0.43 \\
\hline & Guatemala & $2008-2011$ & no data & no data \\
\hline & Honduras & $2005-2009$ & -0.60 & -0.12 \\
\hline & Peru & $2000-2010$ & -2.66 & -0.24 \\
\hline & Average & & -1.79 & -0.20 \\
\hline \multirow{12}{*}{$\begin{array}{l}\text { Centre-right and } \\
\text { right }\end{array}$} & $\begin{array}{l}\text { Bolivia (Plurinational } \\
\text { State of) }\end{array}$ & $2002-2005$ & -1.80 & -0.36 \\
\hline & Colombia & 2000-2009 & -1.78 & -0.18 \\
\hline & Costa Rica & $2002-2006$ & -1.10 & -0.22 \\
\hline & El Salvador & 2000-2009 & -3.83 & -0.38 \\
\hline & Guatemala & $2000-2007$ & +0.20 & -0.03 \\
\hline & Honduras & $2000-2005$ & +1.80 & +0.30 \\
\hline & Mexico & $2000-2010$ & -6.49 & -0.59 \\
\hline & Nicaragua & $2000-2006$ & +2.31 & +0.33 \\
\hline & Panama & $2009-2010$ & no data & no data \\
\hline & Paraguay & $2000-2008$ & -3.86 & -0.43 \\
\hline & Uruguay & $2000-2005$ & +4.46 & +0.74 \\
\hline & Average & & -1.01 & -0.08 \\
\hline
\end{tabular}

Source: Cornia (2014) based on Roberts (2012) for the coding of the political orientation of governments and of www.sedlac.econo.unlp.edu.ar/esp/estadisticas.php for the changes in the Gini coefficients. 
TABLE 4

TREND IN THE GINI COEFFICIENT OF THE DISTRIBUTION OF HOUSEHOLD DISPOSABLE INCOME PER CAPITA, 1980-2000 AND 2000-2010

\begin{tabular}{|c|c|c|c|c|c|c|c|c|c|}
\hline \multicolumn{10}{|c|}{ Transition economies } \\
\hline & OECD & Europe & Asia & Latin America & MENA & South East Asia & South Asia & SSA & World \\
\hline \multicolumn{10}{|c|}{ A: 1980s (starting from earlier available year) and 1990s } \\
\hline $\begin{array}{l}\text { Specific } \\
\text { period for } \\
\text { each } \\
\text { region }\end{array}$ & $\begin{array}{c}1980 \text { to } \\
2001\end{array}$ & $\begin{array}{c}1990 \text { to } \\
1998\end{array}$ & $\begin{array}{c}1980 \text { to } \\
2000\end{array}$ & 1980 to 2002 & 1980 to 2000 & 1980 to 1995 & $\begin{array}{c}1980 \text { to } \\
2000\end{array}$ & 1980 to1995 & \\
\hline $\begin{array}{l}\text { Rising } \\
\text { inequality }\end{array}$ & 14 & 24 & 2 & 14 & 2 & 5 & 3 & 9 & $73(69 \%)$ \\
\hline $\begin{array}{l}\text { No } \\
\text { change }\end{array}$ & 1 & 0 & 1 & 1 & 3 & 0 & 0 & 2 & $8(8 \%)$ \\
\hline $\begin{array}{l}\text { Falling } \\
\text { inequality }\end{array}$ & 6 & 0 & 0 & 3 & 3 & 2 & 2 & 8 & $24(23 \%)$ \\
\hline Total & 21 & 24 & 3 & 18 & 8 & 7 & 5 & 19 & $105(100 \%$ \\
\hline \multicolumn{10}{|c|}{ B: $2000-10$ (or latest available year) } \\
\hline $\begin{array}{l}\text { Specific } \\
\text { period for } \\
\text { each } \\
\text { region }\end{array}$ & $\begin{array}{c}2000 \text { to } \\
2010\end{array}$ & 1998 to 2010 & $\begin{array}{c}2000 \text { to } \\
2009\end{array}$ & 2002 to 2010 & 2000 to 2007 & 71995 to 2009 & $\begin{array}{c}2000 \text { to } \\
2010\end{array}$ & 1995 to 2007 & \\
\hline $\begin{array}{l}\text { Rising } \\
\text { inequality }\end{array}$ & 9 & 13 & 2 & 2 & 4 & 3 & 4 & 7 & $44(41 \%)$ \\
\hline $\begin{array}{l}\text { No } \\
\text { change }\end{array}$ & 4 & 5 & 1 & 1 & 0 & 0 & 1 & 1 & $13(12 \%)$ \\
\hline $\begin{array}{l}\text { Falling } \\
\text { inequality }\end{array}$ & 8 & 6 & 0 & 15 & 4 & 4 & 0 & 13 & $50(47 \%)$ \\
\hline Total & 21 & 24 & 3 & 18 & 8 & 7 & 5 & 21 & $107(100 \%)$ \\
\hline
\end{tabular}

Source: Cornia and Martorano (2012) based on SWIIDv3 and IDLA database. Note: All countries included in Table 4 have at least 10 well-spaced observations for the 30 years considered. Each country has been assigned to one of the three above categories on the basis of a trend analysis and of the difference between the initial and final Gini coefficients for each of the two subperiods considered.

It is thus difficult to argue that the improvements recorded in Latin America are due only to a favourable external environment, world growth, or 'luck'. Other factors, including policy factors, discussed in chapter II hereafter (such as long-term effects of rising educational achievements, changes in economic and social policies and the consolidation of democracy) are likely to explain in part this encouraging trend. 



\section{Underlying causes of the decline of income inequality over 2002-2010}

The analysis of inequality declines is normally conducted by focusing first on its immediate (statistical) causes and then on its underlying causes. In this paper, space limitations forces us to focus mainly on the latter, while reminding that all analyses of the former (Lopez Calva and Lustig 2010, Cornia 2014) suggest that the decline in inequality was driven first and foremost by a decline in the skill premium and - to a lesser extent - by risisng public transfers and remittances and a fall in the urban-rural wage gap. Also an improvement in the distribution of capital incomes apparently took place as well (subject to the caveats of pages 4-5), though its contribution was very modest for the reasons illustrated above. Herafter we focus, in turn, on the underlying causes of the inequality fall, discussing one by one its main possible drivers.

\section{A. An improvement in external conditions}

During the last decade, the rapid growth of the emerging economies entailed a rise in the regional terms of trade index from 100 in 2000 to 117 in 2008 while the volume of exports rose substantially 2010). In turn, migrant remittances grew rapidly in Central America, and to a lesser extent in Bolivia (Plurinational State of), Paraguay and Ecuador, while the regional ratio of official migrant remittances to GDP climbed from 2.2 per cent in the 1990s to 5.4 per cent in 2007-08 (Cornia 2012). Furthermore, between 2002 and 2008 and again in 2010 the region experienced portfolio inflows amounting to 2.4 per cent of the region's GDP.

Given the high concentration in the ownership of land and mines prevailing in the region and their high capital —and skill-intensity, the recent gains in terms of trade generated, ceteris paribus, an unequalizing effect on the functional distribution of income. However, whenever such rents accrued to the state or were taxed and redistributed in a progressive way, their rise generated favourable distributive effects. Yet, the evidence suggests a weak relation between terms of trade and revenue/GDP ratio for Latin America as a whole. The only relatively strong correlation $(r=0.63)$ was found for the eight main commodity exporters for the years 2003-2007.

As for the impact of remittances, the IMF (2005) suggests that their short-term effect tends to be un-equalizing, as only middle class people are able to finance the high costs of illegal migration so that, 
as a consequence, remittances accrue to middle-income families. However, migration may be equalizing if migrant networks develop in the destination countries as observed in the case of El Salvador and Mexico (Acevedo and Cabrera 2014, Campos et al.2014), including because they narrowed the ruralurban income gap. In turn, the increase in capital inflows mainly benefitted large, capital —and skillsintensive firms and banks, and did not ease the access to credit for small labour-intensive firms. In addition, these inflows caused an appreciation of the exchange rate which retarded growth in the laborintensive traded sector, including agriculture, as in the case of Honduras (Klasen et al, 2014). All in all, the partial equilibrium effects of the improvement in international conditions seem unlikely to have led to a large decline in inequality, except possibly in the four to six countries where such a phenomenon was especially marked.

\section{B. Impact of the rapid growth of 2002-2008 and 2010 on income inequality}

In the absence of a CGE model, the general equilibrium effects of the mid-2000s boom in commodity exports, remittances and capital inflows are difficult to trace. Yet, as suggested by Thirlwall (2011), greater currency inflows do relax the foreign exchange constraint to growth and, as a result, may raise employment and improve the distribution of income (Table 5).

TABLE 5

LABOR MARKET TRENDS FOR LATIN AMERICA AS A WHOLE, 1990-2009

\begin{tabular}{cccccccc}
\hline & \multirow{2}{*}{$\begin{array}{c}\text { Activity rate } \\
\text { (\% of pop. of } \\
\text { 15-64 yrs) }\end{array}$} & $\begin{array}{c}\text { Unemployment } \\
\text { rate (\%) }\end{array}$ & & $\begin{array}{c}\text { Wage earners of } \\
\text { total workers (\%) }\end{array}$ & $\begin{array}{c}\text { Formal sector } \\
\text { workers (\%) }\end{array}$ & \begin{tabular}{c} 
Workers paying \\
social security \\
\cline { 7 - 9 }$(\%)$
\end{tabular} & \multicolumn{2}{c}{ Wage } \\
\hline 1990 & 61.0 & 6.2 & 62.6 & 55.0 & 63.3 & 384 & 0.54 \\
2002 & 63.0 & 10.7 & 60.9 & 52.8 & 54.6 & 397 & 0.43 \\
2005 & 63.7 & 9.7 & 61.4 & 53.7 & 59.4 & 405 & 0.44 \\
2007 & 64.2 & 8.0 & 63.0 & 53.0 & 47.0 & 423 & 0.44 \\
2008 & 64.7 & 7.3 & 63.7 & 50.3 & 42.0 & 421 & 0.46 \\
2009 & 64.3 & 8.2 & 63.2 & 50.7 & 38.4 & 434 & 0.47 \\
\hline
\end{tabular}

Source: Cornia (2012) on different tables in CEPAL (2006 and 2008), and SEDLAC database.

\section{An improvement in the distribution of educational achievements}

As noted above, the reduction in the skill premium was the main immediate cause of the recent fall in income inequality. This was -inter alia - due to the redistribution of human capital among households induced by the rise in enrolment rates recorded since the early 1990s and that accelerated in the 2000s (Cruces at al 2014) following a large increase of public spending in education per child 0-14, which rose from 320 US constant \$ PPP in 1990 to 756 in 2000 and to 1451 in 2010.

The increase in the years of education of the labour force and its more equitable distribution generated two effects: a 'price effect' (i.e the deline in the skill premium) and a 'quantity effect' (a more equal distribution of human capital), both of which had an equalizing effect. While the quantity effect is unambiguous, the price effect could be explained also by: (i) a parallel decline in the supply of unskilled labour due to demographic factors or rising educational achievements of formerly uneducated workers; (ii) a possible drop/stabilization in the demand for skilled workers and a rise in the demand for unskilled workers due to technological or macroeconomic factors; (iv) institutional changes (i.e., an increase in 
minimum wages, see later). Thus, the extent to which the 'price effect' is explained by either of these factors remains to be understood fully and is likely to vary from country to country.

To what ane extent was the increase spending on education due to policy choices? To reply this question Cruces et al. (2014) use a simple algorithm by which the public spending in education per child $0-14(\mathrm{G} / \mathrm{N})$ can be decomposed in the the product of the ratio of public spending in education on GDP $(G / Y)$, per capita GDP $(Y / P)$ and the inverse of the share of children in the population $(P / N)$, i.e. G/N = $\mathrm{G} / \mathrm{Y} \times \mathrm{Y} / \mathrm{P} \times \mathrm{P} / \mathrm{N}$. Despite the cross-country problems in accounting of public spending on education - which may bias a bit its results - Table 6 confirms that there was a clear increase in fiscal efforts to support public education. For Latin America as a whole this accounts for 33 per cent of the increase in educational expenditure. Such 'social policy' effect is particularly strong in countries (such as Paraguay, Guatemala, and Nicaragua) which in 1990 had low enrolment rates while it was — as expected - less marked in countries which had already achieved high enrolments such as Panama, Argentina and Colombia. It is also interesting to underscore the important contribution of GDP growth (which increased revenue generation) and the lower but not negligible effect of the decline or slower increase in the cohort of 0-14 old children.

TABLE 6

DECOMPOSITION OF THE INCREASE IN PUBLIC SPENDING IN EDUCATION PER CHILD AGED 0-14 BY ITS MAIN DRIVERS, SELECTED COUNTRIES

\begin{tabular}{lcccc}
\hline & Social policy & Growth & Demographics & Total \\
\hline Argentina & 26.1 & 60.0 & 13.9 & 100.0 \\
Brazil & 32.7 & 45.7 & 21.6 & 100.0 \\
Colombia & 19.0 & 60.4 & 20.5 & 100.0 \\
Guatemala & 45.3 & 46.6 & 8.1 & 100.0 \\
Honduras & 41.0 & 43.4 & 15.6 & 100.0 \\
Nicaragua & 47.7 & 33.3 & 19.0 & 100.0 \\
Panama & 8.0 & 77.2 & 14.8 & 100.0 \\
Paraguay & 60.9 & 26.8 & 12.3 & 100.0 \\
Venezuela (Bolivarian Republic of) & 35.5 & 44.2 & 20.3 & 100.0 \\
\hline L.A. Average & 33.0 & 50.6 & 16.4 & 100.0 \\
\hline
\end{tabular}

Source: Excerpted from Cruces et al. (2014).

\section{The spread of progressive regimes and new policy approaches}

During the last twenty years, the region witnessed a return to and consolidation of democracy. As suggested by Robinson (2010), if political power is concentrated in the hands of the élites, the political system tends to adopt disequalizing policies. In contrast, genuine democracy, greater electoral participation and a 'consolidation of democracy' reduce the concentration of power and facilitate the transition towards non-clientelistic policies. Besides greater democracy, starting from the late 1990s, the region witnessed a shift in political orientation towards centre-left regimes (between 1998 and 2011 the region witnessed the election of 15 left-leaning regimes), due to growing frustration with the disappointing results of the liberal policies implemented in the 1980s and 1990s. Although they helped to re-establish macroeconomic balance, such policies led to a shrinkage of manufacturing and of the industrial working class, a weakening of the unions, rising unemployment, and a substantial enlargement of the informal sector.

While the leftist regimes differ substantially among each other (Panizza 2005), they have evolved into broad coalitions comprising the urban and rural poor, the unemployed and informal sector workers and sectors of business and middle classes. These parties have abandoned any notion of revolutionary break in favour of electoral politics and respect for the institutions of liberal democracy. In all kinds of left of centre regimes, measures in the field of taxation, labour market, social expenditure, and transfers have been more far reaching. The main components of the new model are reviewed hereafter: 


\section{A countercyclical or a-cyclical fiscal policy}

Traditionally, the Latin American countries adopted procyclical and often unsustainable fiscal policies. This stance has been abandoned during the recent decade. A decline in the budget deficit was targeted in all countries, despite an increase in public expenditure. Fiscal deficits have typically been reduced below one per cent of GDP (i.e., lower than the EU and US) and were in several cases turned into surpluses, while the region as a whole recorded a primary surplus between one and two per cent between 2004 and 2008 (Figure 4). Overall, during the fast growth years of 2006 and 2007, the average central government deficit of the region was in equilibrium, though it rose in the difficult years of 2009-2010 in line with the shift towards a countercyclical fiscal management. The strong version of such policy, which requires that a budget surplus is realized during periods of growth so as to finance public deficits during bad years, was followed in Chile and Peru. An a-cyclical version, consisting of balancing the budget or generating a small surplus in good years was followed by most countries due to the difficulties faced by democratic regimes in convincing the electorate of the need for fiscal austerity in periods of rising revenue (Ocampo 2008).

\section{Tax policy}

Tax policy has undergone gradual but deep changes (Cornia et al. 2014). While over 1990-2002 the tax/GDP ratio gradually recovered its 2.7 points decline recorded during the recession of the $1980 \mathrm{~s}$, the regional tax/GDP ratio rose by almost 3.5 points between 2003-2008 and much greater increases were recorded in Argentina (9 points) and Brazil (5 points). Despite the recession of 2009 the regional tax/GDP ratio dropped only 0.35 percentage points, and by late 2000s, Brazil, Argentina, Uruguay and Costa Rica reached levels of taxation similar to those of the US and Japan. Much lower increases in tax/GDP ratios were recorded, however, in most of Central America, while Mexico experienced a small decline. The focus of tax policy changed substantially. While during the 1990s it focused on a reduction of taxes on international trade, a rise of VAT, a lowering or abolition of income tax, and widening of the tax base, during the 2000s tax policy emphasized income tax and reduced tax exemptions, extended the scope of presumptive taxation, cut regressive excises, and introduced indirect taxes on luxury items. A few countries introduced a surrogate tax on financial transactions and/or selective export taxes to tax assets, the distribution of which is highly concentrated and which escape taxation. The increase in world commodity prices contributed to rise of the tax/GDP ratio in seven countries. Yet, such rise began before the commodity boom and aimed at widening the direct and indirect tax base.

\section{FIGURE 4}

\section{TAX REVENUE, PUBLIC EXPENDITURE AND PRIMARY BALANCE, 1995-2010}

(In percentages of GDP)

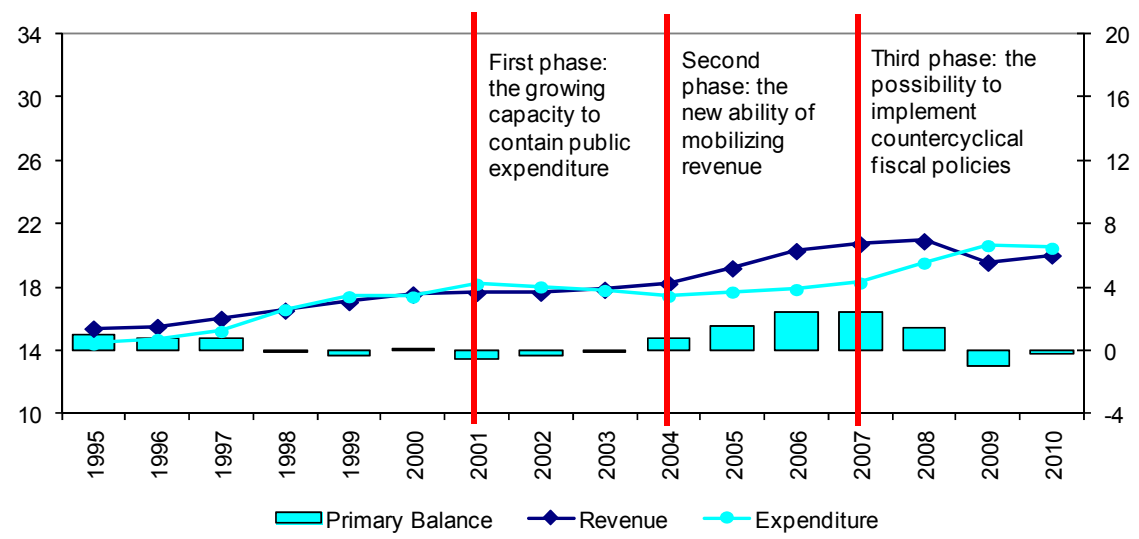

Source: Martorano (2014). 
As a result, while the distribution of income after tax (but before transfers) in 11 Latin American countries had remained broadly unchanged betwee the late 1990s and 2001-2002 and had worsened in Mexico and Nicaragua, during the 2000s the progressivity of taxation improved in relation to the 1990s in 11 of the 12 countries with available data. As shown in Table 7 by the increasingly positive signs of the Reynolds-Smolensky index (which is the difference between the Gini coefficicnt of before and after tax). In addition, the recent revenue increase affected inequality indirectly as it permitted to fund social transfers and public expenditure on education in a non-inflationary way, and to eliminate the highly disequalizing macro instability of the past.

TABLE 7

\begin{tabular}{lccc} 
REYNOLDS-SMOLENSKY INDEX (GINI POINTS) FOR THE 1990s AND 2000s \\
\hline & $1990 \mathrm{~s}$ & $2000 \mathrm{~s}$ & 2000s-1990s \\
\hline Argentina & -1.95 & 1.92 & 3.87 \\
Brazil & -0.70 & 1.40 & 2.10 \\
Chile & -0.78 & 0.27 & 1.05 \\
Costa Rica & -0.98 & 1.24 & 2.22 \\
Ecuador & -0.70 & 0.70 & 1.40 \\
El Salvador & -1.40 & -0.75 & 0.65 \\
Guatemala & -0.77 & 1.20 & 1.97 \\
Honduras & -2.80 & -0.10 & 2.70 \\
Nicaragua & -5.20 & 0.17 & 5.37 \\
Panama & 0.00 & 0.90 & 0.90 \\
Uruguay & -0.20 & 1.20 & 1.40 \\
\hline
\end{tabular}

Source: Cornia et al (2011).

Note: a positive sign of the index indicates that the tax system is progressive, a negative one that it is regressive.

\section{A countercyclical monetary policy}

During periods of bonanza, monetary authorities attempted to control the expansion in money supply, fall in interest rates and credit expansion through an accumulation of reserves and sterilization. Until 2009, only Argentina and Colombia had introduced some capital controls (Ocampo 2008), which have become more common in 2010. In the periods of crisis (as in late 2008 and 2009), most leftist and conservative governments lowered interests rates and expanded lending by public banks, while tolerating even negative real interest rates and slightly higher inflation rates than recommended by the orthodox approach, so as to support the level of output and employment. Monetary policy in Argentina, Peru, Bolivia, and Uruguay aimed also at reducing the extensive (and disequalizing) dollarization of the financial system and at strengthening central bank independence.

\section{Exchange rate regime}

Fixed pegs and free floats were replaced by managed exchange rates aimed at preserving a competitive real exchange rate and avoiding its appreciation during periods of bonanza. Together with an improvement in global economic conditions (see above), this helped to generate current-account surpluses which were used to reduce foreign debt and accumulate currency reserves. However, in 20062007 and again in 2010, this exchange rate policy came under pressure owing to a surge in the world prices of exports, capital inflows, and remittances. Consistent with the new exchange rate policy, most governments adopted a monetary and fiscal stance aimed at avoiding its past pro-cyclical bias. However, without the interventions just mentioned, several countries would have shown stronger symptoms of Dutch disease and accelerating asset price inflation with negative effects on income inequality. Despite these measures, management of the real exchange rate remained a problem in the region, as 14 countries recorded an extra-regional real appreciation in 2010 (CEPAL 2011). 


\section{Trade and external indebtedness}

The free trade policies adopted during the Washington consensus, and which in the 1990s led to a shift in resource allocation against the unskilled labour-intensive sectors, were not overturned, in part because the new exchange rate policies offered in some countries some protection to the tradable sector. In contrast, the pattern of international trade changed perceptibly. While trade within the Free Trade Area of the Americas stalled, intra-regional trade integration increased, especially in the field of manufacturing, and so did South-South trade, particularly the exports of primary commodities to Asian countries. Governments (in particular the left leaning ones) attempted to reduce their dependence on foreign borrowing. Short-term stabilization agreements with the IMF were generally not renewed, while Brazil (in 2005) and Argentina (in 2006) prepaid their outstanding debt to the IMF. Argentina also restructured its foreign debt at a 70 per cent discount, though the leitigation with creditors is still not completely solved. The foreign reserves of the region also grew from about USD150 to almost 550 billion between 2002 and 2009, and the region's gross foreign debt declined from 40 per cent of the regional GDP in 2002 to 17.4 per cent in 2008 and 20.4 in 2009. One can surmise that the distributive effects of exports differentiation and reserves accumulation were likely favourable, as they reduced vulnerability to macroeconomic shocks.

\section{Labour market policies}

Centre-left governments explicitly addressed the problems inherited from the prior two decades, i.e., unemployment, job informalization, falling unskilled and minimum wages, diminishing coverage of social security, and weakening of institutions for wage negotiations and dispute settlements. Argentina enacted income policies consisting of public works, extending coverage of formal employment, and promoting the re-birth of trade unions. In Uruguay and Brazil the governments reinstated tripartite wage bargaining. Meanwhile average wages grew moderately (Table 8), possibly reflecting the greater concern of policymakers for creating jobs than for raising earnings. It also reflects the recognition that, unless backed by increases in productivity, nominal wage raises may fuel inflation with scant effect on real wages. In turn, most left governments and very few conservative ones decreed sizeable hikes in minimum wages (Table 8), which reduced the minimum/average wage ratio with equalizing effects on the wage distribution.

TABLE 8

TREND IN THE INDEX OF REAL MINIMUM WAGES ${ }^{a}$ IN SELECTED COUNTRIES

$(2000=100)$

\begin{tabular}{lrrrrr}
\hline & 2002 & 2004 & 2006 & 2008 & 2010 \\
\hline Chile (2000-2010) $^{\mathrm{b}}$ & 106.8 & 111.3 & 116.3 & 118.3 & 127.7 \\
Brazil (2002) & 114.3 & 121.4 & 145.3 & 160.8 & 182.0 \\
Argentina (2003) & 81.4 & 129.8 & 193.2 & 253.3 & 321.3 \\
Panama (2004-2009) & 105.8 & 107.5 & 108.1 & 109.2 & 113.3 \\
Uruguay (2005) & 88.7 & 77.5 & 153.2 & 176.9 & 196.8 \\
Costa Rica (2006) & 99.5 & 97.6 & 99.5 & 99.5 & 105.8 \\
Bolivia (Plurinational State of) (2006) & 116.0 & 112.0 & 111.1 & 117.0 & 119.9 \\
Honduras (2006-2009) & 104.6 & 114.5 & 127.4 & 131.1 & $225.5^{c}$ \\
Nicaragua (2007) & 105.9 & 113.5 & 128.5 & 141.6 & 174.6 \\
Ecuador (2007) & 112.5 & 122.2 & 130.0 & 146.7 & 161.5 \\
\hline
\end{tabular}

Source: CEPAL (2011).

Notes:

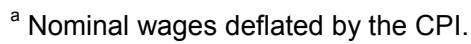

${ }^{\mathrm{b}}$ Years of ruling by LOC regimes.

${ }^{\mathrm{c}}$ Last year available is 2009. 


\section{Rising social expenditure, social assistance and redistribution}

In most countries, public social expenditure started rising in the 1990s but has accelerated its upward trend since the early 2000s (Cornia 2012: Table 12). There still is a huge intra-regional variation in social expenditure but it appears that the rise recorded in the 2000s was proportionately greater in lowincome countries. The funding of this expenditure rise was made possible by the increase in tax/GDP ratios mentioned above, the debt cancellation enjoyed by HIPC countries and higher ODA due to growing 'social conditionality' for achieving the MDGs.

Practically all governments introduced progressive social assistance programmes to complement the coverage of social insurance. These new programmes were funded by the state (with expenditures ranging between 0.2 and 0.8 of GDP, (Fiszbein and Schady 2009, Barrientos 2011), covered an important share of the population at risk, were directed to old and new political constituencies, and comprised conditional transfers aimed at reducing poverty and child labour and at ensuring that children remain in school and have access to health services, employment schemes, training and subsidized employment for the young, and the promotion of small enterprises. In addition, Argentina, Bolivia (Plurinational State of), Chile, and Brazil introduced non-contributory social pensions at a cost of 0.18 to 1.30 per cent of GDP. Their generosity, coverage, design, and targeting generally improved over time, though there still is a large scope for rationalizing some of the preceeding expenditures in this area (as in the case of Brazil), which could improve further the equity of transfers . Yet, as suggested by an analysis of CEPAL (2007) for the years 1997-2003, the rise in public social expenditure likely generated positive redistributive effects, as the distribution of all components of social expenditure is less concentrated than that of private incomes. These are average regional data and things vary between countries. There are also indications that the incidence of social expenditure became more progressive over time and go a long way in redistributing income to the poor (López-Calva and Lustig, 2010). Democratization thus seems to be showing its impact not only on labour policies but also on non-clientelistic redistributive measures. 



\section{Regression analysis}

\section{A. Dataset and bilateral correlation coefficients among explanatory variables}

The hypotheses discussed above in chapter II about the impact of the underlying causes of inequality were tested on the basis of the IDLA dataset (Martorano and Cornia 2011) which includes data for 18 countries for the years 1990-2009. The dependent variable is the Gini coefficient of the distribution of household disposable income per capita (for the sources see Cornia 2012 footnote 19). The explanatory variables were clustered into five groups, i.e., (i) international economic conditions; (ii) rate of growth of GDP per capita; (iii) changes in exogenous factors, such as dependency and activity rates; (iv) the distribution of human capital among workers; (v) policy factors, i.e., the real effective exchange rate and its square, the ratio of direct to indirect taxes, the minimum wage interacted with the share of formal sector workers, and public expenditure on social security/GDP (as there are no time series on social assistance/GDP), and (vi) three dummies, i.e., the 'social democratic' and 'radical-populist' dummies and Polity2 index which proxies the quality of democracy. A low bilateral correlation between the explanatory variables included in regression (Cornia 2012: Annex Table 2) excludes major problems of multicollinearity.

\section{B. Estimation procedure and regression results}

Given the panel structure of the IDLA database, the estimation procedure must take into account that each country is observed over several periods. Such model takes the following form:

$$
G I_{i t}=\alpha+\beta X_{i t}+\eta_{i}+e_{i t}
$$

Where Gini $i_{i t}$ is the coefficient of the distribution of household disposable income per capita, X a vector of the 14 explanatory variables (Annex Table 1), the subscripts i and t refer to the countries and the years of the panel, $\eta_{\mathrm{i}}$ is a time-invariant country's fixed effect, $e_{i t}$ is the idiosyncratic error term, while $\alpha$ and $\beta$ are the parameters to be estimated. Given this a suitable panel estimation procedure is the least square dummy variable (LSDV) (not shown) and of the GMM estimator, which includes among the 
explanatory variables the Gini coefficient retarded one year so as to capture the path-dependent and slow moving nature of Gini, as even large year-to-year changes seldom exceed a couple of Gini points (or $5 \%$ of its level). In addition the dynamic panel-data estimation one-step system GMM procedure allows to take into account problems of reverse causation and endogeneity.

The results of GMM standard Model (first column in Table 9) confirm in most cases the conjectures made in Part 2 about the average regional impact of the underlying causes of the recent decline in income inequality. In particular: (i) as expected, the lagged Gini has a high value and is significant, due to the its persistence mentioned above, (iii) as far as international economic conditions, it appears that, contrary to what argued in Part 2, the gains in terms of trade of the last decade contributed directly and in a statistical significant (if modest) way to the recent decline in inequality, while migrant remittances were not significant at the regional level, and the FDI stock raised inequality strongly and significantly; (iii) GDP growth per capita has, as expected, a negative sign but its parameter is low and so is its significance; (iv) the exogenous yearly changes in dependency rates and activity rates are both small and non-significant, as both of them are heavily trended, as confirmed also by the national case studies in López-Calva and Lustig (2010); (v) the reduction in the inequality of the distribution of educational achievements which should capture the lagged effect of public efforts in the field of education is significantly related to income inequality, thus confirming prior findings ( López-Calva and Lustig 2010); (vi) as for the impact of fiscal policy, the ratio of direct/indirect tax revenue (which rose in all countries over 2002-2009) is found to be significantly and negatively associated to income inequality, thus confirming the conjectures in Part 2. In turn, the ratio of social security/GDP (which also comprises social assistance and non-contributory pensions) is also significant, though the incidence of social insurance (i.e., two-thirds of social security expenditure) is only moderately progressive; (vii) as for the macroeconomic and labour policies, the parameters of the linear and quadratic specification of the real effective exchange rate (REER) are both strongly significant, confirming that a 20 percent real devaluation, for instance, would reduce income inequality by 1.54 points. ${ }^{3}$ As for the labour policies, Table 9 corroborates the predictions of Part 2 about the modest but significant equalizing effect of rises in minimum wages during the last decade; (viii) political economic variables: the two dummy variables are highly significant and have large coefficients (indicating that the policy variables included in the regression do not capture all relevant policy changes (e.g., food subsidies and monetary policy) affecting inequality. In addition, on top of the governments' political orientation, the variable 'Polity2 index' which measures the quality of democratic institutions - shows a strong effect on inequality during the last decade. Altogether, Table 9 confirms most of the hypotheses about the underlying causes of inequality formulated in Part 2, as all the signs of the estimated parameters coincide with those expected ex ante, except in the case of the terms of trade (see later).

As noted, the estimated parameters in the 'standard GMM model' (column 1, Table 9) represent 'average regional effects' that do not take into account the specificities of various country sub-groups. To solve this problem, the 'standard GMM models' was estimated by adding to it interactions with variables which are particularly relevant in specific subgroups, so as to identify the differential impact of some explanatory variables in specific contexts. To start with, the variables 'terms of trade index' and 'migrant remittances/GDP' were interacted for the respective dummies 'commodity exporters' and 'remittances receivers', which were set equal to 1 for the countries where such phenomena are particularly important and zero otherwise (columns 2 and 3). As shown by standard GMM model in Table 9 the terms of trade is significant and negative but the interaction term of the terms of trade is positive and significant (column 2), suggesting that for the subgroup of commodity exporters, inequality rises in line with terms of trade improvements, most likely because of Dutch disease effects. The introduction of this interaction does not perceptibly alter the sign and size of the other parameters, except the significance of public expenditure on social security. Likewise, Model 2 confirms that while remittances on average have a unequalizing effect, they are equalizing one in those nations where such a phenomenon is important and long lasting (such as El Salvador), and such as to generate, for instance, migrant networks, which open the possibility of migrating

The interest rate was included in regression but did not result statistically significant. 
also to low-income people by reducing migration costs. Third, the FDI/GDP variable was interacted with the dummy 'Andean group', i.e. Table 9. Regression results over the period 1990-2009: average regional effects and results for heterogeneous sub-groups, a subgroup where foreign investments in the mining sector are particularly important. Model 3 confirms that the FDI/GDP are unequalizing in all countries but that their effect is more pronounced in this group. Fourth, as suggested by political scientists the quality of democracy (proxied by the Polity2 index) is influenced not only by the effectiveness of democratic institutions but also by its consolidation (i.e. the uninterrupted number of years in which a full democratic rule existed in a country, regardless of the political orientation of the successive governments that run a country) and by the level of popular participation to free elections. In Model 4, the Polity2 index was thus replaced with a composite variable ${ }^{4}$ combining the Polity2 index (with weight 0.5 ), the number of years of uninterrupted democratic rule (with weight 0.25 ) and the turnout rate in political election (with weight 0.25). This alternative specification yields a higher and statistically significant parameter. Finally, Model 5 introduces in the standard model the average import tariff rate with the objective to measure the impact of trade liberalization on inequality. The parameter of such a variable turns out, however, to be statistically non-significant, probably because while trade liberalization had a strong unequalizing initial impact in the 1980s and part of the 1990s, its effect vanished during the 2000s. However, when such a variable is interacted in Model 6 with the 'skill premium' it appears that while trade liberalization, on average, might have been equalizing for the period considered, it was unequalizing in the countries where the skill premium increased, thus offering some support to the 'skills biased technical change' hypothesis.

TABLE 9

REGRESSION RESULTS OVER THE PERIOD 1990-2009: AVERAGE REGIONAL EFFECTS AND RESULTS FOR HETEROGENEOUS SUB-GROUPS

\begin{tabular}{|c|c|c|c|c|c|c|c|c|c|c|c|c|c|c|}
\hline & $\begin{array}{c}\text { GMM } \\
\text { Standard }\end{array}$ & & $\begin{array}{r}\text { GMM-1 } \\
\text { Model } 1\end{array}$ & & $\begin{array}{r}\text { GMM-2 } \\
\text { Model } 2\end{array}$ & & $\begin{array}{r}\text { GMM-3 } \\
\text { Model } 3\end{array}$ & & $\begin{array}{l}\text { GMM-4 } \\
\text { Model } 4\end{array}$ & & $\begin{array}{r}\text { GMM-5 } \\
\text { Model } 5\end{array}$ & & $\begin{array}{r}\text { GMM-6 } \\
\text { Model } 6\end{array}$ & \\
\hline Gini coefficient (t-1) & 0.6375 & $* * *$ & 0.6243 & $* * *$ & 0.5676 & *** & 0.6257 & $* * *$ & 0.6352 & $* * *$ & 0.6380 & *** & 0.6083 & *** \\
\hline Terms of trade index & -0.0104 & $* * *$ & -0.0302 & $* * *$ & -0.0110 & *** & -0.0125 & $* * *$ & -0.0103 & $* * *$ & -0.0105 & *** & -0.0122 & ** \\
\hline Terms of trade index commodity exporters dummy & & & 0.0257 & ** & & & & & & & & & & \\
\hline Remittances/GDP & -0.0431 & & -0.0611 & & 0.0643 & & -0.0311 & & -0.0415 & & -0.0371 & & -0.0346 & \\
\hline Remittances/GDP *Remittances receivers dummy & & & & & -0.2978 & *** & & & & & & & & \\
\hline FDI stock/GDP7 & 0.0353 & $* * *$ & 0.0353 & $* * *$ & 0.0376 & *** & 0.0225 & * & 0.0355 & $* * *$ & 0.0335 & $* * *$ & 0.0240 & $* *$ \\
\hline FDI stock/GDP * Andean group dummy & & & & & & & 0.0328 & * & & & & & & \\
\hline GDP/c growth rate & -0.0402 & * & -0.0444 & ** & -0.0406 & * & -0.0394 & * & -0.0404 & * & -0.0402 & * & -0.0377 & \\
\hline Dependency rate (growth rate) & -0.2021 & & -0.1096 & & -0.3815 & & -0.1434 & & -0.2055 & & -0.1732 & & -0.2135 & \\
\hline Activity rates (growth rate) & 0.0247 & & 0.0421 & & 0.1036 & & 0.0338 & & 0.0255 & & 0.0736 & & 0.1175 & \\
\hline $\begin{array}{l}\text { People with 3ary and 2ary education/ people with primary or no } \\
\text { education }{ }^{a}\end{array}$ & -0.9085 & * & -1.0856 & ** & -0.9746 & ** & -0.8933 & * & -0.8903 & * & -0.9577 & * & -0.7748 & \\
\hline Directlindirect taxes & -0.5307 & * & -0.5927 & * & -0.7026 & ** & -0.3492 & & -0.5255 & & -0.4858 & & -0.3463 & \\
\hline Public expenditure on social security (\%GDP) & -0.1643 & * & -0.1418 & & -0.1314 & & -0.1902 & ** & -0.1636 & * & -0.1122 & & -0.1820 & \\
\hline REER & -0.0233 & * & -0.0346 & ** & -0.0250 & * & -0.0257 & ** & -0.0234 & * & -0.0225 & & -0.0341 & * \\
\hline $\operatorname{REER}^{\wedge} 2$ & 0.0001 & * & 0.0001 & ** & 0.0001 & * & 0.0001 & ** & 0.0001 & * & 0.0001 & * & 0.0001 & $* *$ \\
\hline Minimum wage index *share of formal sector workers on the total & -0.0109 & ** & -0.0115 & ** & -0.0117 & ** & -0.0107 & ** & -0.0110 & ** & -0.0112 & ** & -0.0107 & \\
\hline Social-democratic dummy & -0.3746 & * & -0.3979 & * & -0.4582 & ** & -0.3522 & * & -0.3656 & & -0.4607 & * & -0.4264 & * \\
\hline Radical-populist dummy & -1.6840 & $* * *$ & -1.9414 & $* * *$ & -1.7178 & *** & -1.4827 & $* * *$ & -1.6856 & $* * *$ & -1.7083 & $* * *$ & -0.6538 & \\
\hline Polity2 index (quality of democracy) & -0.1740 & $* * *$ & -0.1642 & $\star * \star *$ & -0.1736 & *** & -0.1623 & $* \star \star *$ & & & -0.1828 & *** & -0.2131 & $\star * * *$ \\
\hline $\begin{array}{l}\text { Composite index of quality of democratic institutions, } \\
\text { consolidation of democracy and electoral turnout }\end{array}$ & & & & & & & & & -0.3483 & $* * *$ & & & & \\
\hline Import tariff rate $(\%)$ & & & & & & & & & & & 0.0092 & & -0.1768 & * \\
\hline Import tariff rate*skill premium & & & & & & & & & & & & & 0.1053 & ** \\
\hline
\end{tabular}

4 I owe this suggestion to Bruno Martorano of the University of Florence. 
Table 9 (conclusion)

\begin{tabular}{|c|c|c|c|c|c|c|c|c|c|c|c|c|c|c|}
\hline & $\begin{array}{c}\text { GMM } \\
\text { Standard }\end{array}$ & & $\begin{array}{l}\text { GMM-1 } \\
\text { Model } 1\end{array}$ & & $\begin{array}{r}\text { GMM-2 } \\
\text { Model } 2\end{array}$ & & $\begin{array}{l}\text { GMM-3 } \\
\text { Model } 3\end{array}$ & & $\begin{array}{c}\text { GMM-4 } \\
\text { Model } 4\end{array}$ & & $\begin{array}{r}\text { GMM-5 } \\
\text { Model } 5\end{array}$ & & $\begin{array}{r}\text { GMM-6 } \\
\text { Model } 6\end{array}$ & \\
\hline Constant & 23.0956 & $* \star \star *$ & 25.4785 & $* * *$ & 26.6505 & $* * *$ & 23.9626 & $* * *$ & 23.3249 & $* * *$ & 22.5951 & $* * *$ & 25.3196 & $* * *$ \\
\hline Observations & 288 & & 288 & & 288 & & 288 & & 288 & & 275 & & 255 & \\
\hline Number of countries & 18 & & 18 & & 18 & & 18 & & 18 & & 18 & & 18 & \\
\hline
\end{tabular}

Source: Cornia (2012).

Notes: * significant at $10 \%$; ${ }^{* *}$ significant at $5 \%$; ${ }^{* * *}$ significant at $1 \%$.

Commodity exporters are Bolivia (Plurinational State of), Chile, Colombia, Ecuador, Peru, and Venezuela (Bolivarian Republic of); 'remittances recipients' are El Salvador, Guatemala and Nicaragua; the Andean group includes Bolivia (Plurinational State of), Colombia, Ecuador, Peru and Venezuela (Bolivarian Republic of).

${ }^{a}$ Both variables are expressed in terms of their yearly variations.

In conclusion, with all the limitations imposed by incomplete data, the variable specifications adopted for some variables, measurement errors and other econometric issues, the results of Table 9 provide a fairly consistent picture of the positive, negative or non-significant inequality impact of the variables. 


\section{Inequality during the crisis of 2008-2012 and prospects for its further reduction}

\section{A. Inequality changes over $\mathbf{2 0 0 8 - 2 0 1 2}$}

The above analysis has focused on the inequality changes aand their drivers over the period 2002-2010. Most of these years (e.g. the 2002-2008 period) were years of fairly rapid growth and favourable global conditions that - directly or indirectly - generated some positive effects on the Latin American economies. However, the question immediately arises whether inequality continued falling during the turbulent years of 2009-2012 (no data are yet available for 2013, except for Argentina). New standardized data recently released by CEDLAS permit to determine whether inequality rose or continued to head downwards during these more volatile years. Had inequality stopped falling or began rising during these years, one would be tempted to consider the 2002-2008/9 gains as 'cyclical' rather than 'structural'.

In this regard, Figure 5 shows that — despite the growth deceleration of 2008-2009, the sluggish growth of 2011-2012, and worsening global conditions inequality comtinued declining in all 11 countries for which there are complete Gini data for the years 2008-2012. In fact, for some countries, inequality declined even faster than during the prior six years. A simple statistical test (not shown) for these last four years and these countries finds that changes in GDP growth rates and Gini coefficients are orthogonal, thus suggesting that the inequality decline which began in 2002-2003 is structural and depends mainly on factors other than the buisiness cycle. Yet, in 2012 there was a perceptible slowdown in the pace of decline, as the average Gini coefficicnt fell by only 0.2 points.

However, CEPAL's Social Panorama (2013, p.80) argues that "La desigualdad distributiva ha mantenido la tendencia a la reducción que empezó a manifestarse hace un decenio". Its Annex Table IA2, shows in fact that the Q10/Q1-4 ratio improved in seven of the 11 countries for which this index is available for both 2011 and 2012. But the CEPAL data show that the changes in the income share of the bottom 40 percent and Gini coefficient for the same 11 countries improved in five, worsened in four and stagnated in two. Everything considered, therefore, it appears that while in 2009-2011 inequality fell as fast, or faster, than over 2002-2008, in 2012 the decline continued in half of the countries while in the other half it recorded a moderate increase. 


\section{FIGURE 5}

TREND IN THE GINI COEFFICIENT OF PER CAPITA HOUSEHOLD INCOME, 2008-2012

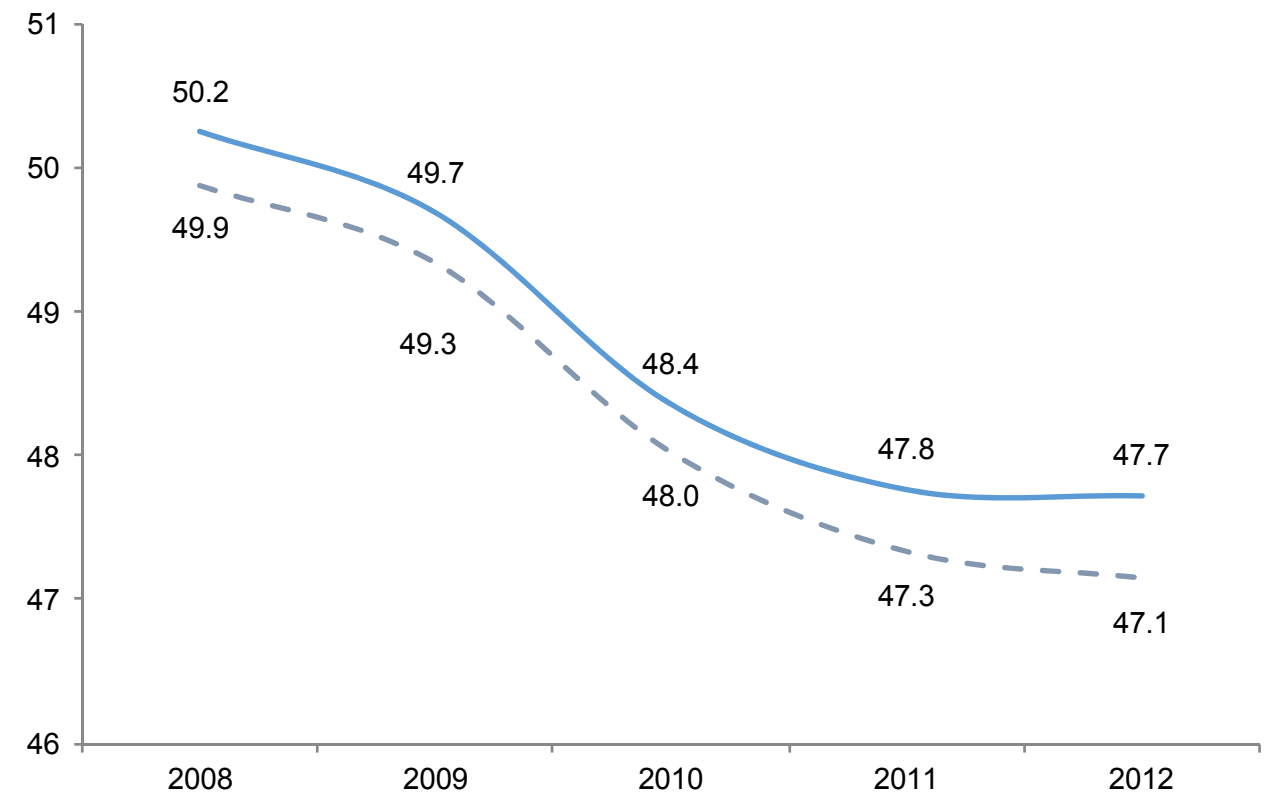

Source: author's compilation on CEDLAS and CEPAL data.

Notes:

${ }^{1}$ The trend is based on a balanced panel of 11 countries with complete data for the years 2008-2012, i.e.: Argentina, Bolivia (Plurinational State of), Brazil, Colombia, Costa Rica, Ecuador, El Salvador, Mexico, Panama, Peru and Uruguay.

2 The dotted line includes Uruguay (which witnessed a higher-than-average Gini drop over 2008-2012. The solid line excludes it.

How can one explain such surprising trend? The World Bank (2010) argued that, unexpectedly, labour markets were little affected by the 2009 crisis. While unemployment rose in eight of the 11 countries it analysed in, the average increment in jobless was only 0.9 while the average activity rate fell negligibly (Table 5). In turn, real wages remained relatively strong or rose (except in hard-hit Mexico and Ecuador) in part due to the low inflation of 2009 (ibid). Informality rose modestly (0.3-0.4 points on average) mainly in countries with rising unemployment. In addition, the skilled/unskilled, formal/informal and male/female wage gaps continued to fall, most likely because of the adoption of vigorous labour market policies and the continuous rise in the supply of workers with secondary or higher education. Finally, the countercyclical fiscal policy implemented in 2009-2010 (Figure 4) —and, possibly, during the subsequent years - permitted to continue expanding highly equalizing social assistance programs which have gained huge political support in the region because of their lowish fiscal cost and non negligible inequality impact. A further investigation of the very recent inequality decline is however needed.

\section{B. Further reducing inequality through a deepening of the recent reforms}

Despite the decline recorded over 2002-2008 and again over 2009-2012, income inequality in many Latin American countries remains among the highest in the world. Particularly in Central America and the Andean countries, future efforts will have to deepen the comparatively timid policy reforms introduced during the 2000s, as well as on removing the structural causes of inequality by broadening the access of the poor and the middle class to land, credit, investment opportunities, high quality 
secondary and tertiary education and public subsidies. A further reduction of inequuality will also require a re-calibration of the region's pattern of development and approach to global economic integration, so as to embed future inequality declines in a sustainable pattern of growth. All this will have to happen, however, in a global context which might be less favourable than the one of 2003-2008. These two points are discussed hereafter.

\section{Improve further the equality of opportunities among social classes}

There is still considerable space to improve inequality through the set of 'social democratic' reforms introduced in the 2000s. To start with, progress in raising average secondary and tertiary enrolment rates and reducing educational inequality was not accompanied by similar gains in the quality of education. As shown by a six-country ECLAC (2010) study of the PISA science scores of 15 year old children belonging to four quartiles of the ISEC index (which approximates the socioeconomic and educational level of their families of origin), there still are considerable performance differences in favour of children from the upper ISEC group who often attend better quality private secondary schools (Table 10), a topic which represented a major campaigning item during the January 2014 Chilean elections.

TABLE 10

NET TERTIARY ENROLMENT RATES, TOTAL AND BY INCOME QUINTILES, 1990-2010

\begin{tabular}{|c|c|c|c|c|c|c|c|c|c|c|c|}
\hline \multicolumn{12}{|c|}{ Equivalized income quintiles } \\
\hline & & Total & 1 & 2 & 3 & 4 & 5 & Q5/Q1 & Difference & Q5-Q1 & Difference \\
\hline \multirow[t]{3}{*}{ Argentina } & 1991 & 19.0 & 7.7 & 13.6 & 5.5 & 21.5 & 41.1 & 5.33 & & 33.4 & \\
\hline & 2000 & 28.2 & 9.2 & 13.0 & 24.8 & 35.3 & 55.3 & 5.98 & 0.65 & 46.0 & 12.68 \\
\hline & 2011 & 30.9 & 18.0 & 25.3 & 29.5 & 38.2 & 56.6 & 3.15 & -2.83 & 38.7 & -7.38 \\
\hline \multirow[t]{3}{*}{ Brazil } & 1990 & 6.1 & 0.4 & 0.5 & 1.8 & 5.6 & 24.2 & 62.96 & & 23.8 & \\
\hline & 1999 & 9.3 & 0.9 & 1.5 & 3.1 & 8.2 & 35.4 & 40.39 & -22.57 & 34.6 & 10.77 \\
\hline & 2009 & 16.3 & 3.3 & 5.1 & 9.7 & 20.4 & 48.8 & 14.84 & -25.54 & 45.5 & 10.92 \\
\hline \multirow[t]{4}{*}{ Colombia } & 1996 & 13.6 & 4.2 & 4.7 & 7.1 & 12.5 & 36.4 & 8.77 & & 32.3 & \\
\hline & 2000 & 17.1 & 8.3 & 5.7 & 10.5 & 17.7 & 40.9 & 4.95 & -3.83 & 32.6 & 0.32 \\
\hline & 2010 & 23.9 & 8.5 & 11.7 & 18.5 & 27.8 & 55.8 & 6.56 & 1.61 & 47.3 & 14.73 \\
\hline & & 11.3 & & & & & & 13.30 & & 24.8 & \\
\hline \multirow{2}{*}{ Average for $15 \mathrm{LA}$ countries } & & 15.9 & & & & & & 12.10 & -1.20 & 33.2 & 8.40 \\
\hline & & 22.0 & & & & & & 10.00 & -2.10 & 39.6 & 6.30 \\
\hline
\end{tabular}

Source: Author's elaboration on the basis of SEDLAC data (n.d.).

This persistent gap reduces the chances of children of lower socioeconomic status of being selected during university-admission examinations. As a result, while both the ratio and the difference between the tertiary enrolment rate of children belonging to the top and bottom income quintile declined in Argentina, these indexes continued to rise in Colombia (Table 10). In Brazil (and for the region as a whole) the ratio fell, but the absolute difference rose. To continue improving the educational opportunities of children of low-income families as a way to equalize life chances and the future income distribution, governments thus need to broaden tertiary education access by improving the quality of teaching in secondary education and reducing the direct and opportunity cost of education borne by poor children. All this is all the more necessary, given the possibility of a further 'technological shock' which might shift labour demand towards workers with tertiary education. Without corrective measures, it cannot be excluded that the skill premium may start rasing again in the future. 


\title{
2. Raising revenue/GDP ratios - and improve the targeting of social expenditure
}

The above and other state interventions will need to be financed in a non-inflationary manner. Despite the increase in tax/GDP ratio recorded in the 2000s and improvements in tax progressivity, in a large part of the region the trend towards rising taxation needs to continue so as to preserve macroeconomic stability and increase the redistribution via the budget, much of it in the form of in-kind services which equalize opportunities. In this regard, a gradual increase of the effective tax/GDP ratio to its potential level would generate additional revenue equal to 3.5-4.0 per cent of GDP for the region as a whole. Figure 6 suggests there still is room to do so in most of the region, at no cost to economic efficiency as shown by the recent case of Uruguay. This measure would also reduce the inequality of post-tax income distribution. For instance an increase in income tax revenue of three GDP points would reduce post-tax inequality by three Gini points, bringing the average Latin American country close to the levels of redistribution achieved via taxation in western Europe (Cornia et al. 2014).

\section{FIGURE 6 \\ RELATION BETWEEN TAX REVENUE AND LOG GDPIC IN 92 DEVELOPED AND DEVELOPING COUNTRIES, 2007}

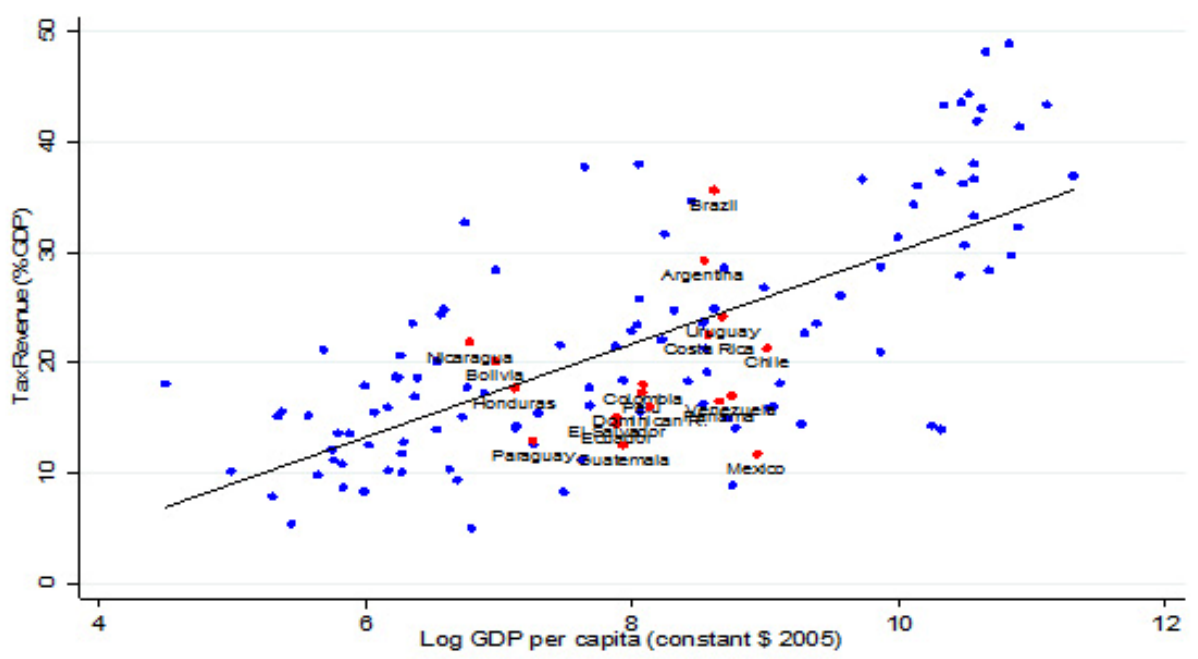

\begin{abstract}
Source: Cornia et al (2011). Notes: the 'revenue effort index' is the ratio of effective to potential tax/GDP ratio (both net of social security contributions). The potential tax/GDP ratio was calculated by regression on a panel of 92 developing and developed countries and including as independent variables GDP/c, the share of (relatively easy-to-tax) manufacturing on GDP, and the share of hard-to-tax agriculture on GDP.
\end{abstract}

Especially in countries with an already high revenue/GDP ratio (Argentina, Brazil and Nicaragua, see Figure 6) important distributive gains can be obtained also (or mainly) by improving the quality and targeting of social expenditure. Better budgeting, spending reviews, impact evaluations, and policy feedbacks are therefore needed, as shown inter alia by Lustig et al. (2013) in their study on 'Commitment to equity in Latin America'. As suggested by recent political events (as in the case of Brazil), high taxes or their increase would be legitimized and effectively executed if governments simultaneously and equitably expanded the provision of good quality public services while avoiding the usual state capture by the elites. A comparison of the redistributive effects of fiscal operations in different groups of countries shows that some 80 percent of the redistributive effect is due to public expenditure (Cornia 2014a). There is a need to improve allocation and quality of spending. 


\section{Embed the decline of income inequality in a sustainable pattern of growth}

If implemented with care over the next few years, the above 'social-democratic reforms' could go a long way in further reducing income inequality. But structural reforms will be required -in both the poor and rich parts of the region - to deal with the deep-seated structural inequality that has affected the region since the beginning of the last century.

In economies where agriculture is still an important source of employment, there is a need to support smallholders' competitiveness by increasing their access to land (still a major problem in most of Central America, a few Andean countries, Paraguay and parts of Brazil), investing in rural infrastructure, reducing the urban bias of public policy, and adopting an exchange rate that favours the traded sector.

A second structural problem that needs fixing is the segmentation of the labour market and persistent spread of informal employment. In fact, wage inequality and the urban-rural income gap reflect to a large extent the gap between formal and informal wages. Informality also feeds inequality by narrowing the scope of contributory social protection and exacerbating the need for social assistance transfers. While the expansion of the formal sector depends on broader issues of capital accumulation, labour productivity and modernization of production, the problems could be in part tackled immediately as several informal workers are currently employed in formal sector firms.

A third structural problem affecting long-term growth and inequality concerns the pattern of economic integration in the world economy, and the implicit structure of production of the region. As argued by Ocampo (2012), trade liberalization during the last quarter century has led to rapid export growth but only to a moderate growth of GDP and labour productivity, persistent vulnerability to external shocks, a 're-primarization' of exports and risk of 'de-industrialization'. A continuation of this pattern of trade integration and production is thus unlikely to help reducing inequality because of its modest growth impact and because it shifts resources to the capital-intensive primary commodity and non-traded service sectors. This problem could be approached by adopting an 'open economy industrial policy' that supports development of labor-intensive manufacturing and service sectors by means of active production measures, technological upgrading, entry into new sectors, a strengthened regional integration, and a rebalancing of the asymmetries that characterize Latin America's trade with China. Some authors (Katz 2013), however, see the return to a new industrializing phase of the Latin American development as problematic as the creation of a new nationalist bourgeoisie is hampered by the opposition of large commodity exporters who obstruct the reindustrialization process. Finally, if unaddressed, other structural biases of the Latin American economy - low savings, dependence on foreign capitals, and continued pressures towards sudden real appreciation during bonanzas or sudden real depreciation in periods of crisis - may well block future inequality gains by retarding the shift to a long-term sustainable, equitable and structurally different growth path. 



\section{Bibliography}

Acevedo C. and M. Cabrera (2014), 'Social Policies or Private Solidarity? The Equalizing Role of Migration and Remittances in El Salvador' in Cornia (2014) op. cit

Altimir, O. (1996). 'Economic Development and Social Equity'. Journal of Interamerican Studies and World Affairs, 38(2/3): 47-71.

Alvaredo, F. (2010). 'The Rich in Argentina over the Twentieth Century 1932-2004'. In A. Atkinson and T. Piketty (eds), Top Incomes: A Global Perspective, vol. II. Oxford: Oxford University Press.

Alvaredo, F. and J.Londono Velez (2013). 'High Incomes and persona taxation in a developing economy: Colombia 1993-2010”Working Paper No. 12, Commitment to Equity Initiative, March 2013.

Barrientos, A. (2011). 'On the Distributional Implications of Social Sector Reforms in Latin America'. WIDER Working Paper 2011/69. Helsinki: UNU/WIDER.

Behrman, J., N. Birdsall, and M. Székely (2000). 'Economic reform, and wage differentials in Latin America’. RES Working Paper 4235. Washington, DC: Inter-American Development Bank.

Birdsall, N., N. Lustig, and D. McLeod (2011). 'Declining Inequality in Latin America: Some Economics, Some Politics'. Working Paper 1120. New Orleans: Tulane University.

Burdin, G., F. Esponda and A.Vigorito (2013), "The recent evolution of income inequality in Uruguay: an analysis based on household surveys and income tax micro-data" Iastituto de Economia-UDELAR, Montevideo, powerpoint presentation: http://stonecenter.tulane.edu/uploads/Andrea_Vigorito_CEQ1385569837.pdf.

Campos-Vasquez, R. G. Esquivel and N. Lustig (2014), “The Rise and Fall of Income Inequality in Mexico, 1989-2010" in Cornia (2014), op.cit.

CEPAL (2005, 2006, 2007, 2008, 2013). 'Panorama Social de América Latina'. Santiago de Chile: CEPAL.

CEPAL (2010, 2011). 'Balance Preliminar de las Economías de América Latina y el Caribe’. Santiago de Chile: CEPAL.

Cornia, G.A. (2012), "Inequality Trends and their Determinants: Latin America over 1990-2010” WIDER Working Papers 2012/09.Helsinki, UNU-WIDER.

Cornia, G.A. (ed.) (2014), Falling Inequality in Latin America: Policy Changes and Lessons, Oxford University Press, Oxford.

Cornia, G. A., J. C. Gómez Sabaíni, and B. Martorano (2011). 'A New Fiscal Pact, Tax Policy Changes and Income Inequality: Latin America during the Last Decade’. WIDER Working Paper 2011/70. Helsinki: UNU-WIDER. 
Cornia, G. A., and B. Martorano (2012). “"Development policies and income inequality in selected developing regions, 1980-2010” UNCTAD Discussion Paper 210, November 2012.

Cruces,G., C. García Domench and L. Gasparini (2014), "Inequality in Education: Evidence for Latin America” in Cornia (2014), op. cit.

Engerman, S. L., and K. L. Sokoloff (2005). 'Colonialism, Inequality and Long-Run Paths of Development'. NBER Working Paper 11057. Cambridge, MA: National Bureau of Economic Research.

Fiszbein, A., and N. Schady (2009). Conditional Cash Transfers: Reducing Present and Future Poverty. Washington, DC: World Bank.

Frankema, E. (2009). 'The Colonial Roots of Land Inequality: Geography, Factor Endowments, or Institutions?'. The Economic History Review 63(2): 418-51.

Gasparini, L., G. Cruces, L. Tornarolli, and M. Marchionni (2009). A Turning Point? Recent Developments on Inequality in Latin America and the Caribbean'. Documento de Trabajo 81. De la Plata: CEDLAS Universidad Nacional de La Plata.

Gasparini, L., and G. Cruces (2010). 'A Distribution in Motion: the Case of Argentina'. In L. López-Calva and N. Lustig (eds), Declining Inequality in Latin America: A Decade of Progress?. Washington, DC and New York: Brookings Institution Press and UNDP.

IMF (International Monetary Fund) (2005). World Economic Outlook. Washington, DC: IMF.

Koujianou-Goldberg, P., and N. Pavcnik (2007). 'Distributional Effects of Globalization in Developing Countries’. NBER Working Paper 12885. Cambridge, MA: National Bureau of Economic Research.

Jimenez, J.P. "Desigualdad y tributación sobre los altos ingresos, powerpoint presented at the XXVI Seminario Fiscal of ECLAC, santiago 20-22 January 2014.

Katz, C. (2013), "Manifestaciones de la Crise en America Latina y la Paradojas del Neodesarrolismo Argentino”, Cadernos CRH, Salvador, Vol. 26, n.27, Jan-April 2013.

Klasen S., T Otter, and C. Villalobos Barría (2014), The Dynamics of Inequality Change in a Highly Dualistic Economy’ In Cornia (2014) op. cit.

Londoño, J. L., and M. Székely (2000). 'Persistent Poverty and Excess Inequality'. Journal of Applied Economics, 3(1): 93-134.

López-Calva, L. F., and N. Lustig (2010). Declining Inequality in Latin America: A Decade of Progress?. Washington, DC and New York: Brookings Institution Press.

Lustig, N., C. Pessino and J. Scott (2013). "The Impact of Taxes and Social Spending on Inequality and Poverty in Argentina, Bolivia, Brazil, Mexico, Peru and Uruguay: An Overview,"Working Papers 1313, Tulane University, Department of Economics.

Martorano, B., and G. A. Cornia (2011). 'The IDLA Dataset” Available at: www.wider.unu.edu/research/ current-programme/en_GB/Impact-of-Economic-Crisis/.

Martorano, B. (2014), 'The cyclicality of fiscal policy in Latin America, 1990-2010”, mimeo. University of Florence.

Ocampo, J. A. (2008). ‘The Latin American Economic Boom’. Revista de Ciencia Política, 28(1): 7-33.

Ocampo, J. A. (2012), “The Development Implications of External Integration in Latin America”, WIDER Working Papers 2012/48, UNU-WIDER, Helsinki.

Palma, J.G. (2011) “Homogeneous middles vs. heterogeneous tails, and the end of the 'Inverted-U': the share of the rich is what it's all about," Cambridge Working Papers in Economics 1111, Faculty of Economics, University of Cambridge

Panizza, F. E. (2005). 'Unarmed Utopia Revisited: The Resurgence of Left-of-Centre Politics in Latin America'. Political Studies, 53(4): 716-34.

Prados de la Escosura, L. (2005). 'Growth, Inequality, and Poverty in Latin America: Historical Evidence, Controlled Conjectures’. Working Paper 05-41 (04). Madrid: Department of Economic History and Institutions, Universidad Carlos III de Madrid.

Roberts, K. (2012). 'The Politics of Inequality and Redistribution in Latin America's Post-Adjustment Era'. WIDER Working Paper 2012/08. Helsinki: UNU-WIDER.

Robinson, ( 2010 ). 'The Political Economy of Redistributive Policies'. In L. F. Lopez-Calva and N. Lustig (eds), op. cit.

Sainz, P., and A. Calcagno (1992). 'En busca de Otra Modalidad de Desarrollo'. CEPAL Review, 48 (December). 
Taylor, L. (2005). 'External Liberalization, Economic Performance and Distribution in Latin America and Elsewhere’. In G. A. Cornia (ed.), Inequality, Growth and Poverty in an Era of Liberalization and Globalization. Oxford: Oxford University Press.

Thirlwall, P. (2011). 'Balance of Payments Constrained Growth Models: History and Overview’. Studies in Economics 1111. Kent: Kent School of Economics.

World Bank (2010). 'Did Latin America Learn to Shield its Poor from Economic Shocks?’. WB Brief 61273. Washington, DC: World Bank. 

TABLE A.1

DEFINITION OF VARIABLES USED IN REGRESSION ANALYSIS

\begin{tabular}{|c|c|c|c|}
\hline Variable & Description & $\begin{array}{l}\text { Unit of } \\
\text { measurement }\end{array}$ & Data source \\
\hline $\begin{array}{l}\text { Gini coefficient } \\
\text { of disposable } \\
\text { income/capita }\end{array}$ & Gini on income & Index (0-100) & $\begin{array}{l}\text { IDLA database (CEDLAS } \\
\text { plus other sources for } \\
\text { missing years) }\end{array}$ \\
\hline $\begin{array}{l}\text { Terms of trade } \\
\text { index }\end{array}$ & International terms of trade, goods and services & Index $2000=100$ & CEPALSTAT \\
\hline $\begin{array}{l}\text { Remittances/GD } \\
\mathrm{P}\end{array}$ & Workers' remittances/GDP & Share of GDP & UNCTAD \\
\hline FDI stock/GDP & Net stock of foreign direct investment/GDP & Share of GDP & UNCTAD \\
\hline $\begin{array}{l}\text { GDP/c growth } \\
\text { rate }\end{array}$ & Growth rate of GDP per capita & Rate of growth & $\begin{array}{l}\text { ERS International } \\
\text { Macroeconomic Dataset }\end{array}$ \\
\hline $\begin{array}{l}\text { Dependency } \\
\text { rate (growth } \\
\text { rate) }\end{array}$ & $\begin{array}{l}\text { Ratio of dependents (people younger than } 15 \text { or } \\
\text { older than } 64 \text { ) to the working age population }\end{array}$ & $\begin{array}{l}\text { Percentage } \\
\text { variation }\end{array}$ & WDI \\
\hline $\begin{array}{l}\text { Labour force } \\
\text { participation } \\
\text { (growth rate) }\end{array}$ & $\begin{array}{l}\text { Labour participation rate ( } \% \text { of total population aged } \\
15-64+\text { ) }\end{array}$ & $\begin{array}{l}\text { Percentage } \\
\text { variation }\end{array}$ & WDI \\
\hline $\begin{array}{l}\text { Human capital } \\
\text { distribution } \\
\text { among workers }\end{array}$ & $\begin{array}{l}\text { People with 3ary \& 2ary education/ people with } \\
\text { primary or no education }\end{array}$ & $\begin{array}{l}\text { Share on } \\
\text { population aged } \\
15 \text { yrs and over }\end{array}$ & Barro and Lee \\
\hline $\begin{array}{l}\text { Public } \\
\text { expenditure on } \\
\text { social } \\
\text { security/GDP }\end{array}$ & Public expenditure on social security/GDP & Ratio & $\begin{array}{l}\text { CEPALSTAT \& national } \\
\text { sources }\end{array}$ \\
\hline REER & Indices of real effective exchange rate & Index $2000=100$ & $\begin{array}{l}\text { CEPAL's Econ Survey of } \\
\text { Latin America and the } \\
\text { Caribbean }\end{array}$ \\
\hline $\begin{array}{l}\text { Minimum wage } \\
\text { index }\end{array}$ & Minimum wage index & Index $2000=100$ & CEPALSTAT \\
\hline $\begin{array}{l}\text { Informal sector } \\
\text { employment }\end{array}$ & $\begin{array}{l}\text { Share of informal sector employment on total } \\
\text { employment }\end{array}$ & $\begin{array}{l}\text { Percentage } \\
\text { share }\end{array}$ & $\begin{array}{l}\text { CEPALSTAT, ILO, } \\
\text { SEDLAC and data from } \\
\text { national statistical offices }\end{array}$ \\
\hline $\begin{array}{l}\text { Social } \\
\text { democratic }\end{array}$ & $\begin{array}{l}\text { Dummy denoting a country/year with social- } \\
\text { democratic government }\end{array}$ & $\begin{array}{l}1 \text { (social- } \\
\text { democratic) } \\
0 \text { (all other } \\
\text { cases) }\end{array}$ & Author's compilation \\
\hline Radical-populist & $\begin{array}{l}\text { Dummy denoting a country/year with radical-populist } \\
\text { government }\end{array}$ & $\begin{array}{l}1 \text { (populist) } \\
0 \text { (all other } \\
\text { cases) }\end{array}$ & Author's compilation \\
\hline Polity2 Index & $\begin{array}{l}\text { Index of democracy measuring the quality of } \\
\text { democratic institutions }\end{array}$ & Index 0-10 & Polity IV Project \\
\hline $\begin{array}{l}\text { Democratic } \\
\text { participation }\end{array}$ & Vanhanen index of participation & $0-100$ & $\begin{array}{l}\text { Vanhanen measures of } \\
\text { democracy } \\
\text { 1820-2010, avaialb }\end{array}$ \\
\hline $\begin{array}{l}\text { Democratic } \\
\text { consolidation }\end{array}$ & No. of years since the most recent regime change & & Polity IV Project \\
\hline $\begin{array}{l}\text { Composite index } \\
\text { of democracy }\end{array}$ & $\begin{array}{l}\text { Average of Polity2 index (weight } 0.5) \text {, yrs of } \\
\text { uninterrupted democracy (weight } 0.25 \text { ) and index of } \\
\text { participation to political elections }(0.25)\end{array}$ & Index 0-10 & Author's compilation \\
\hline
\end{tabular}

Source: Author's compilation. For the sources cited in the last column see Cornia (2012). 


\section{Series:}

\section{E C L A C Macroeconomics of Development}

\section{Issues published}

\section{A complete list as well as pdf files are available at www.eclac.org/publicaciones}

149. Income inequality in Latin America: Recent decline and prospects for its further reduction, Giovanni Andrea Cornia (LC/L.3847), 2014.

148. Impactos de las reformas recientes de política fiscal sobre la distribución del ingreso. El caso de Bolivia (Estado Plurinacional de), Tatiana Genuzio (LC/L.3844), 2014.

147. Evaluating policies to improve TFP in four large Latin American countries, Claudio Aravena, André Hofman, Juan Fernández y Matilde Más (LC/L.3840), 2014.

146. Experiencias internacionales en transparencia fiscal, María Dolores Almeida (LC/L.3765), 2014.

145. Empleo, crecimiento sostenible e igualdad, Jürgen Weller y Cornelia Kaldewei (LC/L.3743), 2013.

144. La descentralización y el financiamiento de políticas sociales eficaces: impactos, desafíos y reformas. El caso de la Argentina, Oscar Cetrángolo y Ariela Goldschmit (LC/L.3740), 2013.

143. Análisis de la reforma tributaria en el Ecuador, 2001-2012, Luis Castro, Víctor Aguiar y Mayra Sáenz, (LC/L.3739), 2013.

142. Política monetaria, cambiaria y macroprudencial para el desarrollo. Volatilidad y crecimiento en América Latina y el Caribe, 1980-2011, Ramón E. Pineda-Salazar y Rodrigo Cárcamo-Díaz (LC/L.3733), 2013.

141. Política tributaria y protección del medioambiente. Imposición sobre vehículos en América Latina, Juan C. Gómez Sabaíni y Dalmiro Morán (LC/L.3732), 2013.

140. El desempeño mediocre de la productividad laboral en América Latina: una interpretación neoclásica, Claudio Aravena y Juan Alberto Fuentes (LC/L.3725), 2013.

139. Generating inclusive and sustainable growth. The role of policy and multilevel fiscal institutions, Ehtisham Ahmad (LC/L.3718), 2013.

138. Políticas fiscales para el crecimiento y la igualdad, Ricardo Martner, Andrea Podestá e Ivonne González (LC/L.3716), 2013.

137. Desarrollo minero y conflictos socioambientales. Los casos de Colombia, México y Perú, Miryam Saade (LC/L.3706), 2013.

136. Rasgos estilizados de la relación entre inversión y crecimiento en América Latina y el Caribe, 1980-2012, Luis Felipe Jiménez y Sandra Manuelito (LC/L.3704), 2013.

135. Impactos de las reformas recientes de política fiscal sobre la distribución de los ingresos. El caso de Perú, Andrés Escalante (LC/L.3699), 2013.

134. Política fiscal y crecimiento económico. Consideraciones microeconómicas y relaciones macroeconómicas, José Félix Sanz-Sanz e Ismael Sanz Labrador (LC/L.3638), 2013.

133. Política tributaria en América Latina: agenda para una segunda generación de reformas, Juan Carlos Gómez Sabaíni y Dalmiro Morán (LC/L.3632), 2013.

132. Descentralización, inversión pública y consolidación fiscal: hacia una nueva geometría del triángulo, Roberto Fernández Llera (LC/L.3622), 2013.

131. La arquitectura financiera mundial y regional a la luz de la crisis, José Antonio Ocampo (LC/L.3584), 2013.

130. Política tributaria para mejorar la inversión en América Latina, Claudio Agostini y Michel Jorratt (LC/L.3589), 2013. 

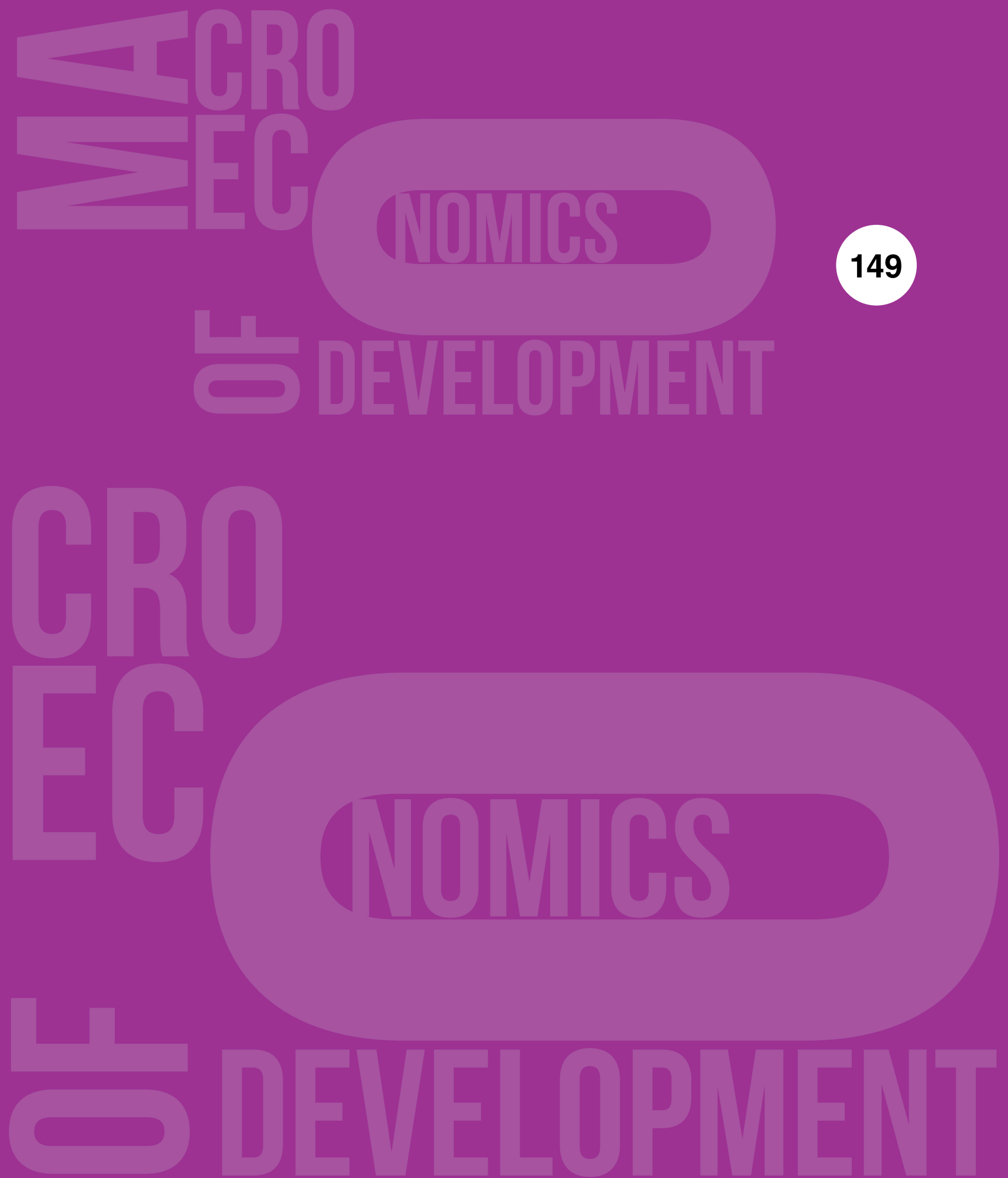

\section{MACROECONOMICS OF DEVELOPMENT}

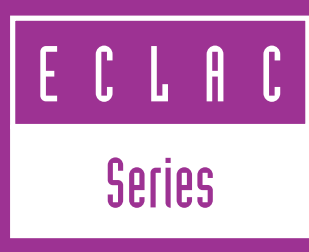

ECONOMIC COMMISSION FOR LATIN AMERICA AND THE CARIBBEAN

COMISIÓN ECONÓMICA PARA AMÉRICA LATINA Y EL CARIBE

www.eclac.org 